\title{
Establishment of okadaic acid resistant cell clones using a cDNA expression library
}

\author{
T Sandal', R Ahlgren ${ }^{1}, \mathrm{~J} \mathrm{Lillehaug}^{2}$ and SO Døskeland ${ }^{\star, 1}$ \\ 1 Department of Anatomy and Cell Biology, University of Bergen, Årstadveien 19 \\ $\mathrm{N}-5009$ Bergen, Norway \\ 2 Department of Molecular Biology, HIB, Tormøhlensgt. 55, N-5020 Bergen, \\ Norway \\ * Corresponding author: SO Døskeland, Department of Anatomy and \\ Cellbiology, Årstadveien 19, N-5009 Bergen, Norway. Tel: 4755586375; \\ Fax: 4755586360; E-mail: stein.doskeland@iac.uib.no
}

Received 27.12.00; revised 27.2.01; accepted 6.3.01

Edited by C Borner

\begin{abstract}
The mechanism whereby the universal apoptogen and serine/ threonine phosphatase inhibitor okadaic acid (OA) kills cells, is still unclear. To create a novel tool for probing of $O A$ action, fibroblasts were selected for OA-resistance after infection with a retroviral Jurkat T-cell cDNA expression library. Twenty-one clones were selected. Two of these (OAR1, OAR2) were studied in detail. OAR1 and 2 had each a retrovirally introduced short cDNA, corresponding to a human gene (oar1 and oar2, respectively) with unknown function. Reintroduction of oar1 or oar2 cDNA into wild-type cells reproduced the OA-resistant phenotype. OAR1 and 2 were cross-resistant to other phosphatase inhibitors (calyculin A, cantharidin), but not to staurosporine or microinjected Cytochrome $c$, thus, indicating a disturbance in a limited number of death pathways, upstream or independent of apaf-1/caspases-3/9. The action of $O A$ involved caspase-dependent and caspase-independent components. Both components were less efficient in OAR1 and 2 , than in wild-type cells. Subtle differences existed between OAinduced phosphoprotein patterns in wild-type cells, OAR1, and OAR2, indicating that a narrow selection of protein phosphorylation events had been targeted. We propose that the clones have defects in a hitherto non-elucidated signal pathway linking OA-induced protein phosphorylation to initiation of a death execution pathway provided with a caspase-dependent amplification loop. The novel OAresistant cell clones will be used to elucidate the significance for apoptosis of oar1 and 2, their link to altered protein phosphorylation, and the potential link of the latter to initiation of apoptosis. Cell Death and Differentiation (2001) 8, 754-766.
\end{abstract}

Keywords: apoptosis; okadaic acid; retrovirus; cloning; protein phosphorylation; multidrug resistance

Abbreviations: OAR, okadaic acid resistant; OA, okadaic acid; zVADfmk, Z-Val-Ala-DL-Asp-fluoromethylketon; PP; protein phosphatase; CA, cantharidin; Cal A, calyculin A; caspase, cysteinaspartate protease; Cyt $c$, Cytochrome $c$; IU, infectious units; mdr, multidrug resistance; $\mathrm{P}$-gp, $\mathrm{P}$-glycoprotein

\section{Introduction}

Apoptosis is a tightly regulated form of cell death recognised by morphology and implemented by mechanisms that are basically conserved throughout evolution from nematode to man. ${ }^{1-3}$ The cysteine-aspartate proteases (caspases) have a dominant role in mammalian cell apoptosis both as early amplifiers of an apoptotic signal and as apoptosis executioners, ${ }^{4-6}$ but there is emerging evidence that regulated cell death may occur also independently of caspases. ${ }^{7-9}$ Whereas signalling through limited proteolysis is irreversible, signalling through protein phosphorylation is reversible, and therefore well suited to participate in the early pathways leading to cell death commitment. Several cellular proteins involved in apoptosis such as members of the Bcl-2 family, ${ }^{10,11}$ cell cycle regulators ( $\left.\mathrm{p} 53, \mathrm{pRB}, \mathrm{Cdks}\right),{ }^{12,13}$ cell death receptors, ${ }^{14}$ and cytoskeletal components (vimentin, tau, laminins), ${ }^{15-17}$ are modified by phosphorylation (for review see Gjertsen et al). ${ }^{18}$

The algal toxin okadaic acid (OA) is a potent inhibitor of a subgroup of serine/threonine phosphatases, including the two most abundant phosphatases, PP1 and PP2A, in mammalian cells. ${ }^{19-21}$ Although prolonged exposure to low concentrations of OA promotes tumour formation, ${ }^{22}$ acute exposure of cells to moderate or high concentrations of OA invariably leads to apoptosis. ${ }^{23-28}$ OA-induced death can be both dependent and independent of gene transcription, protein synthesis, p53 expression, and caspases. ${ }^{24,29-32}$ The molecular mechanisms involved in OA-induced apoptosis remain to be elucidated, and it has even been questioned if cell death induced by $\mathrm{OA}$ and other PP1/ PP2A inhibitors depends on PP inhibition. ${ }^{33,34}$

Attempts have been made to establish OA-resistant cell lines as a tool to dissect the complex apoptogenic action of OA. In all cell clones which have developed OA resistance the major abnormality reported is up-regulation of the $\mathrm{P}$ glycoprotein (P-gp) membrane pump resulting in an increased efflux of $\mathrm{OA} .^{35-37}$ In one case this was associated with a mutation in PP2A, making this enzyme sub-sensitive to $O A{ }^{38}$ So far, such cell lines have yielded limited information about events downstream of PP inhibition. One reason may be that the prolonged exposure to $\mathrm{OA}^{35,37}$ may have favoured the induction of multidrug resistance and thereby prevented cells from developing protective alterations in their death signalling pathways.

Retroviral cDNA expression cloning is a powerful technique to create cells expressing a cell death resistant phenotype, and which allows the isolation of the cDNA responsible for the resistance. ${ }^{39-42}$ We here report the successful use of retroviral-mediated insertion of a cDNA library from Jurkat T-cells into target cells, to create OAresistant cell clones. Kissil et al. have reported the successful use of antisense cDNA library to identify important genes responsible for interferon-induced apopto- 
sis, including the DAP-kinase. ${ }^{43}$ There are also a growing number of examples of dominant negative effects of fragments of proapoptotic proteins. ${ }^{39,44-46}$ For these reasons the library had both sense- and antisense oriented cDNAs and had not been selected for long cDNAs.

The properties of two of the 21 OA-resistant cell clones produced will be reported in detail.

\section{Results}

\section{Optimisation of the selection system}

High transduction is required in order to perform efficient cDNA library screening by retrovirus expression cloning. Only freshly prepared virus was used for the experiments to be reported below. A number of rodent cell lines were tested for ability to be efficiently transduced using virus containing the Lac- $Z$ reporter gene in a pBabe derived virus vector. Only the $\mathrm{C} 3 \mathrm{H} / 10 \mathrm{~T} 1 / 2 \mathrm{Cl} 8$ mouse embryonic fibroblasts were transduced with more than $50 \%$ efficiency. In fact, complete (>99\%) transduction was achieved in such cells, as determined by $\beta$-galactosidase staining (not shown).

Another critical parameter to perform efficient library expression screening for cell clones with death-resistant phenotype is to use a death inductor that is close to $100 \%$ efficient as cell killer. Otherwise, cells that have not acquired resistance will survive, leading to a high number of false positives. In the present case, $\mathrm{C} 3 \mathrm{H} / 10 \mathrm{~T} 1 / 2 \mathrm{Cl} 8$ cells were incubated with the apoptogen okadaic for $24 \mathrm{~h}$ at increasing concentrations. Less than $0.05 \%$ of cells resisted $0.7 \mu \mathrm{M}$ OA treatment. In order to ensure a minimum of falsely resistant isolates it was decided to select with $0.75 \mu \mathrm{M}$ OA for $48 \mathrm{~h}$.

\section{Selection and initial characterisation of cell clones resistant to OA-induced death}

Figure 1A gives a schematic overview of the procedure for producing and selecting resistant cell clones. In order to screen for cDNAs with potential to block OA-induced apoptosis, $10^{7} \mathrm{C} 3 \mathrm{H} / 10 \mathrm{~T} 1 / 2 \mathrm{Cl} 8$ fibroblasts were transduced with $3 \times 10^{6}$ infectious units (IU) (three times the size of the library) of retrovirus containing a Jurkat T-cell cDNA library. These conditions ensure that nearly the entire cDNA library is represented in the screening, and gives an optimal balance between high transduction and the requirement that most infected cells only receive one single infection. ${ }^{47}$

After two rounds of selection with $0.75 \mu \mathrm{M}$ OA, no viable colonies were recovered from the control-transduced cells. Twenty-one cell clones remained viable and able to form colonies from the cells transduced with the Jurkat cell library. In order to find whether or not the 21 clones were more resistant to OA than the parental cells also in short term experiments, the clones were scored for apoptosis after treatment for $3 \mathrm{~h}$ with $100 \mathrm{nM}$ or $500 \mathrm{nM}$ OA (Figure $1 \mathrm{~B})$. Whereas wild-type cells and lac- $z$ expressing transduced cells showed less than $1 \%$ viability (less than $1 \%$ morphologically non-apoptotic cells) after $3 \mathrm{~h}$ exposure to $500 \mathrm{nM} \mathrm{OA}$, the 21 selected clones showed from 3 to $55 \%$ viability. Most clones had higher survival scores than the control cells also in response to $100 \mathrm{nM}$ OA. Two of the clones with highest OA resistance (OAR1 and OAR2) were analysed further, and will hereafter be referred to as OAresistant (OAR) cell clones. As shown in Figure 2 these two cell clones showed less rounding (Figure 2C, D) and chromatin condensation (Figure $2 \mathrm{G}, \mathrm{H}$ ) than the wild-type cells (Figure 2B, F) in response to $250 \mathrm{nM}$ OA for $3 \mathrm{~h}$. It was noted that clone OAR2 had a slightly higher replication time (26 against $22 \mathrm{~h}$ ) and a higher percentage of cells in metaphase/anaphase at any given time (9\% against $3 \%)$ than the OAR1 clone and all types of control cells (not shown). This suggested that OAR2 had acquired a genotype distinct not only from the control cells, but also from OAR1.

\section{Identification of the cDNAs transduced into OAR1 and OAR2, and verification of their protective effect by re-introduction into control cells}

In order to identify the retrovirally-introduced cDNAs possibly responsible for the OA-resistant phenotype of OAR1 and OAR2, RT-PCR was performed on RNA extracts employing primers specific for the retrovirus vector. The RT-PCR produced distinct cDNA bands of about 500 - and $700 \mathrm{bp}$, for OAR2 and OAR1 respectively, as revealed by agarose electrophoresis (not shown). The exact size of the cDNA inserts was 419 bp (oar2) and 622 bp (oar1), as revealed by sequencing (Figure 3). Neither oar2 nor oar1 revealed significant similarity to genes with known function by BLAST 2.0 sequence similarity search in the NCBI databases $\left(\right.$ GenBank ${ }^{48}$; DDJB (DNA databank of Japan) ${ }^{49}$; $\mathrm{EMBL}^{50}$ ). The oar1-cDNA in position 67-607nts, in the sense orientation, was $97 \%$ identical to a region on human chromosome 11 clone RP11-876F8 map 11q14, whose sequence is in progress (AC: AP000795). Oar2 appeared to be nearly identical to human DNA sequences within a gene (AC: AK002158) with unknown function, recently isolated from human prostate mRNA. Oar2 had one region (nucleotides 226-376) which is identical to the predicted last part of the reading frame of AK002158. The rest of oar2 corresponded, in antisense direction, to sequences within the 3' UTR of AK002158. There was a potential large open reading frame including part of the antisense sequence and the whole of the sense sequence. There are two possible explanations for the anti-apoptotic effect of oar2. One is that it acts through antisense RNA by decreasing the expression of AK002158 or a closely related and so far unreported gene. Alternatively, it may encode a peptide of 130 amino acids, using the alternative initiation codon CUG. Examples of messenger RNAs where translation is initiated by CUG initiation codon includes several isoforms of human fibroblast growth factor 2 (FGF-2), ${ }^{51} \mathrm{c}-\mathrm{myc}^{52}$ and the p50 isoform of the apoptosis regulator Bag-1. ${ }^{53}$ The putative Oar2 peptide includes the carboxyterminal part of the predicted protein coded for by AK002158. Such a peptide may act both in the same direction as AK002158 having a dominant positive function or may block the action of AK002158 (by dominantly negative function). These results indicate that both isolated cDNAs represent functionally 'novel' genes. 
A.

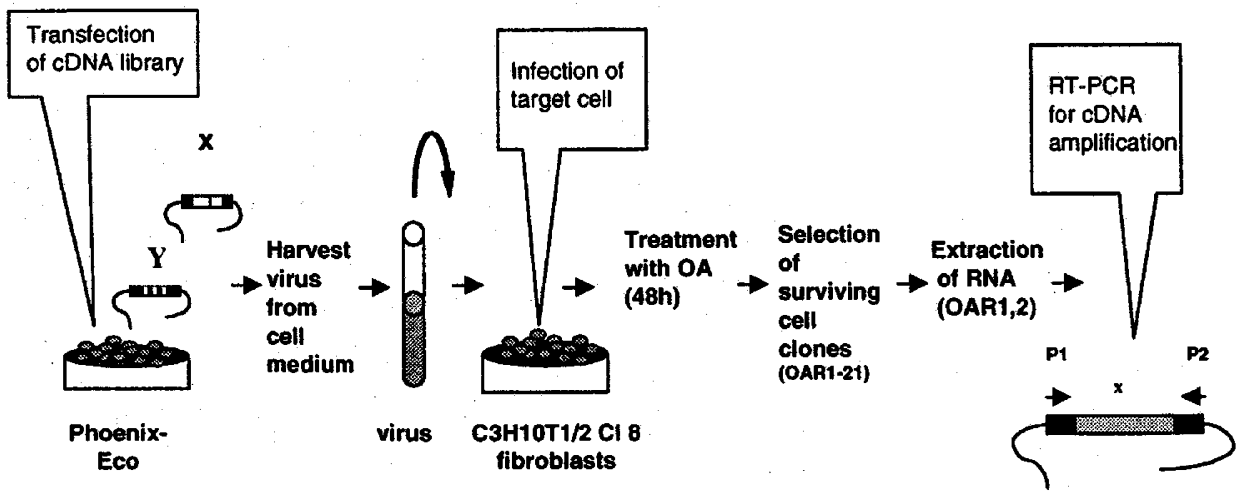

B.

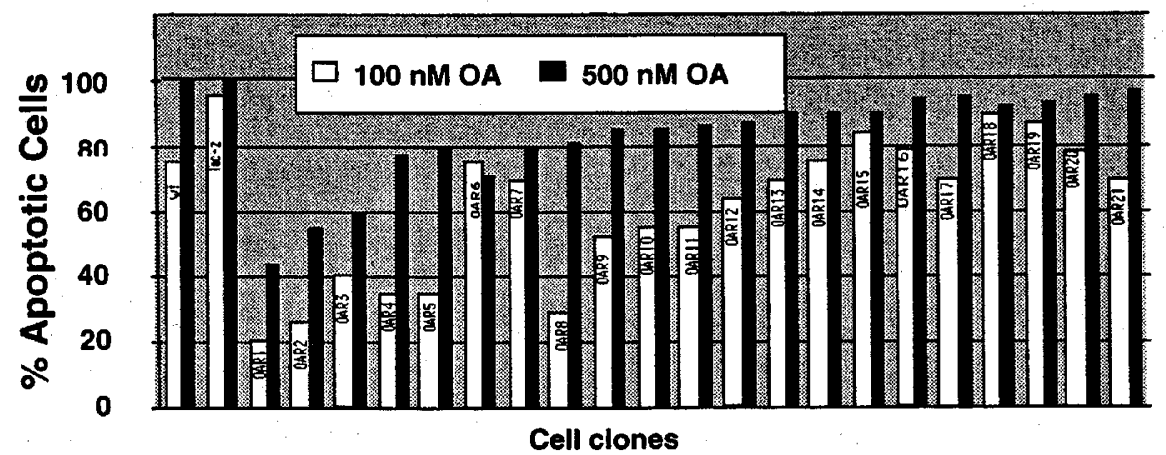

Figure 1 Retrovirus based cDNA-library expression screening and the resulting surviving sub-clones. (A) Schematic presentation of the retrovirus cDNA-library expression cloning. A bi-directional cDNA library from Jurkat T-cells, containing potential anti-apoptotic genes $(x, y)$, in a pBabeMN retrovirus vector was converted into retrovirus by transfection (CaPO4 precipitation) into the virus producer cell line, Phoenix-Eco. The Phoenix-Eco cell medium, containing retrovirus ( $>$ $5 \times 10^{6} \mathrm{IU} / \mathrm{ml}$ ), was used to infect target $\mathrm{C} 3 \mathrm{H} / 10 \mathrm{~T} 1 / 2 \mathrm{Cl} 8$ fibroblasts. Infected cells were subjected to normally lethal concentration $(750 \mathrm{nM})$ of the apoptosis inducer OA. Surviving cells were isolated and subcloned. The inserted cDNA sequence was recovered by RT-PCR of RNA extracted from the expanded cell clones, using primers specific for the virus vector. (B) The subclones (OAR1-21) of surviving cells were tested for their OA-sensitivity, in response to $100 \mathrm{nM}$ (open bars) or $500 \mathrm{nM}$ (filled bars) OA for $3 \mathrm{~h}$. Apoptotic cells were scored by microscopy as described in the legend to Figure 2

The fact that OA-resistant cell clones were not produced when control cells were exposed to OA suggested that spontaneous development of $\mathrm{OA}$ resistance was rare in $\mathrm{C} 3 \mathrm{H} / 10 \mathrm{~T} 1 / 2 \mathrm{Cl} 8$ cells, and is an unlikely explanation for the OA resistance in OAR1 and 2. It was, however, important to rule out this possibility by showing that reintroduction of the cDNA of oar1 and 2 into wild-type cells could recreate OA resistance. Isolated cDNAs from OAR1 and OAR2 were therefore re Cloned into a retrovirus vector carrying the neomycin selection gene, pBabeMN-I$\mathrm{Neo}$, and transfected into wild-type $\mathrm{C} 3 \mathrm{H} / 10 \mathrm{~T} 1 / 2 \mathrm{Cl} 8$ cells to verify their anti-apoptotic effect. Stably transfected cell clones containing either the pBabeMN-oar1-constructs or the pBabeMN-oar2 construct, were established and verified by RT-PCR and Southern blot analysis.

Transfectants were tested for their sensitivity towards $\mathrm{OA}$ treatment. Cells expressing either of the isolated cDNAs were more protected from OA-induced apoptosis than either non-transfected control cells or cell clones expressing the lac-z reporter gene (Table 1). This indicates that cDNAs originally isolated from OAR1 and OAR2 are involved in disruption of the OA-induced apoptotic-signalling pathway in $\mathrm{C} 3 \mathrm{H} / 10 \mathrm{~T} 1 / 2 \mathrm{Cl} 8$ cells. Interestingly, transfected cells, carrying the cDNA of OAR1 in opposite direction (oar1 as), appeared to be slightly more sensitive to OA than control cells (Table 1 ).

\section{The OA-resistant cell clones OAR1 and OAR2 were cross-resistant to several PP-inhibitors, unrelated to multidrug resistance}

Okadaic acid is a potent inhibitor of important members of the protein phosphatase (PP) family, but there is little direct evidence that phosphatase inhibition is essential for OAinduced apoptosis. In order to know if the OA resistance of OAR1 and 2 was related to PP inhibition, the PP inhibitors 

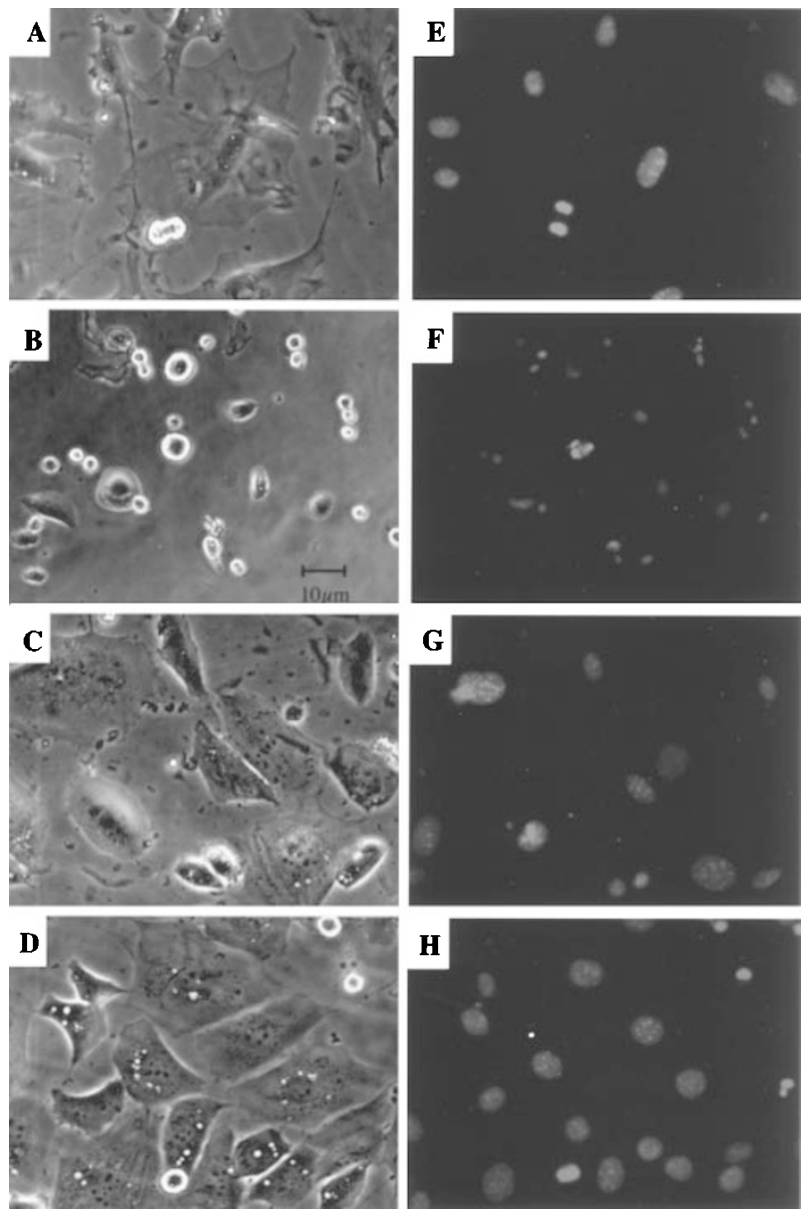

Figure 2 The morphological appearance of wild-type cells and OA-resistant sub clones. Effect of $\mathrm{OA}$ treatment. $\mathrm{C} 3 \mathrm{H} / 10 \mathrm{~T} 1 / 2 \mathrm{Cl} 8$ wild-type cells were treated for $3 \mathrm{~h}$ with $(\mathbf{B}, \mathbf{F})$ or without $(\mathbf{A}, \mathbf{E}) 250 \mathrm{nM} O A$. The OA-resistant cell clones OAR1 (C, G) and OAR2 (D, H) were treated for $3 \mathrm{~h}$ with $250 \mathrm{nM} \mathrm{OA}$. The left-hand panels (A-D) show cell appearance under phase contrast microscopy. Note cell shrinkage and rounding in panel B. The right-hand panels $(\mathbf{E}-\mathrm{H})$ show staining of nuclear DNA with Hoechst 33342 . Note the condensed nuclei in panel F. Magnification $550 \times$ (see size bar in panel B)

calyculin $\mathrm{A}(\mathrm{Cal} \mathrm{A})$ and cantharidin $(\mathrm{CA})$ were compared to $\mathrm{OA}$ as apoptogens for control cells $(\mathrm{C} 3 \mathrm{H} / 10 \mathrm{~T} 1 / 2 \mathrm{Cl} 8-\mathrm{LAC}-\mathrm{Z}$ and $\mathrm{C} 3 \mathrm{H} / 10 \mathrm{~T} 1 / 2 \mathrm{Cl} 8$ wild-type) and for OAR1 and OAR2. CalA, $C A$, and $O A$ are structurally different. CalA differs also from $\mathrm{OA}$ in being more potent for PP1, while CA is less potent than OA for PP2A and PP1. ${ }^{21,54,55}$ OA had a molar potency for cell death induction in $\mathrm{C} 3 \mathrm{H} / 10 \mathrm{~T} 1 / 2 \mathrm{Cl} 8$ cells (Figure $4 \mathrm{~A}$ ) that was between that of CalA (Figure 4B) and CA (Figure 4C). OAR1 and OAR2 were cross-resistant to OA, CalA and CA (Figure 4). The fact that three structurally distinct PP-inhibitors with widely different potency all showed impaired death induction in OAR1 and OAR2 indicated that a PP-dependent death pathway had been targeted in the selected cell clones, arguing that protein phosphatase inhibition was essential for OA-induced death.

An alternative explanation for the resistancy of the OAR cells for the three compounds could be due to multidrug resistance. Upregulation of the multidrug resistance related
A.

\section{OAR1 Length: 622 (GCG format)}

1 tgtgctggaa aggggaccag gacaaggatg gtaagagatt ctctctgtgg

51 tagagaatgg ctgaaagcag gggaaaaagg ggagcaggaa tgctgaaaag

101 ccaaagcttc aaggcccggg tgtataggat ctgcctaaga ctgagactgg

151 gtcattagag ccaggaatct catcttctct ccaagagctt caaactgagt

201 aaccagcaat aatagtctac caactgggac caggacaaag gatggtaaga

251 gattctctct gtggtagaga gaatggctga aagcagggga tggatcagca

301 atactgaaa aaacgttctg gtacccaagg aaccactcta agcacaatgr

351 acactgate toutggagg aattggaagt gtgtggtacg cttcaggtaa

351 acatattcta tcactggagg aatrggaagt gtgtggtacg cttcaggtaa

401 caatagcaaa aacaattacc aaacctagtc taactactaa ctagattgac

451 tcaactcaga agtagaggta cacacatttc caagagtaaa tactatttac

501 ttttgtatct gctgttttc cacatacaat taccagtatt tagtaacaat

551 tatgttctgt acccacaaa gcaagaaaga atgaccccat tgtcaagaat

601 aagaagcaag aatcccagca ct

\section{B}

\section{OAR2 Length: 419 (GCG format)}

1 ctggaaagag atagggcagg ctgcaggget ggtggctcag ggctcagggg 51 gcccaacte tctgtgctgc tctgaggcac tgccttcaat ctcaggttgg 101 cagcacaaag ctgetgagag tcccagtgtc acgeccagac cccacaatgc 151 cagggaggaa gacaggttct atctaaggag agatcttcca tccccacctc 201 tgcggactt tactcacttc tcaggggcct gccaggaaga ctacaggcag 251 taccaggcc aagtggaatg gcaggtggag aagcacaagc aagagctgag 301 gagaacgag agtactggg catrocaggo gcttctcaga gtcaaacact 301. ggagaacgag agtaactggg catacaagge gcttctcaga gtcaaacact 401 ggtggetctt tccagcaca

\section{C.}

\section{OAR2 predicted amino acid sequence (GCG format)}

1 CWKEIGQAAG LVAOGSGGPN SLCCSEALPS ISGWQHKAAE SPSVTPRPH 51 AREEDRFYLR RDLPSPPLRT FTHFSGACQE DYRQYQAKVE WQVEKHKQEL 101 RENESNWAYK ALLRVKHLML LHYEICGDRA GCRAGGSFQH

Figure 3 Sequences of oar1 and oar2. (A) Nucleotide sequence of oar1 cDNA, position 1-622. (B) Nucleotide sequence of oar2 cDNA, position 1-419. A possible CTG start codon (28-31) is shown in bold. (C) Predicted amino acid sequence of oar2 cDNA (coded by nucleotides $32-419$ in panel B) was deduced from CTG start codon (28-31 in panel B). For details regarding the constructs see Materials and Methods

Table 1 Re-establishment of OA-resistant cell clones by transfection of oar1 and oar2

\begin{tabular}{|c|c|c|}
\hline \multirow[b]{2}{*}{ Cell clones } & \multicolumn{2}{|c|}{$\%$ Apoptotic Cells (mean \pm S.E.M.) } \\
\hline & $250 \mathrm{nM}$ OA & 500 nM OA \\
\hline wildtype & $45 \pm 3.7$ & $77.5 \pm 3.0$ \\
\hline pBMN- & $40.5 \pm 1.6$ & $66.7 \pm 7.5$ \\
\hline pBMN-Z & $38.3 \pm 2.3$ & $69.8 \pm 6.7$ \\
\hline OAR1 & $18.3 \pm 2.5$ & $48.8 \pm 1.0$ \\
\hline pBMN-oar1 (s) & $25 \pm 3.9$ & $53.2 \pm 8.2$ \\
\hline pBMN-oar1 (as) & $52.7 \pm 2.3$ & $80.4 \pm 7$ \\
\hline OAR2 & $14.5 \pm 1.0$ & $53 \pm 5.9$ \\
\hline pBMN-oar2 (s) & $15.5 \pm 1.0$ & $58.7 \pm 2.9$ \\
\hline
\end{tabular}

In order to verify the effect and specificity of oar1 and oar2, the cDNAs were reintroduced into virus vector (pBMN) carrying the gene for neomycin resistance. $\mathrm{C} 3 \mathrm{H} / 10 \mathrm{~T} 1 / 2 \mathrm{Cl} 8$ wild-type cells were stably transfected with pBMN-virus vector containing no insert $(-)$, lac-Z-gene (Z), oar1 in sense orientation (oar1(s)) and anti-sense orientation (oar1(as)), and oar2 in sense orientation (oar2(s)). Each cell clone was treated for $4 \mathrm{~h}$ with $250 \mathrm{nM}$ and $500 \mathrm{nM} \mathrm{OA}$, fixed and scored for apoptosis. Data represent the mean of at least six experiments \pm S.E.M.

P-gp channel has been shown in most cell clones that developed spontaneous OA resistance during prolonged exposure to low concentrations of OA. ${ }^{35-37}$ Such cells were still sensitive to cantharidin, ${ }^{28}$ suggesting that $m d r-1$ upregulation had not taken place in OAR1 or OAR2. In 

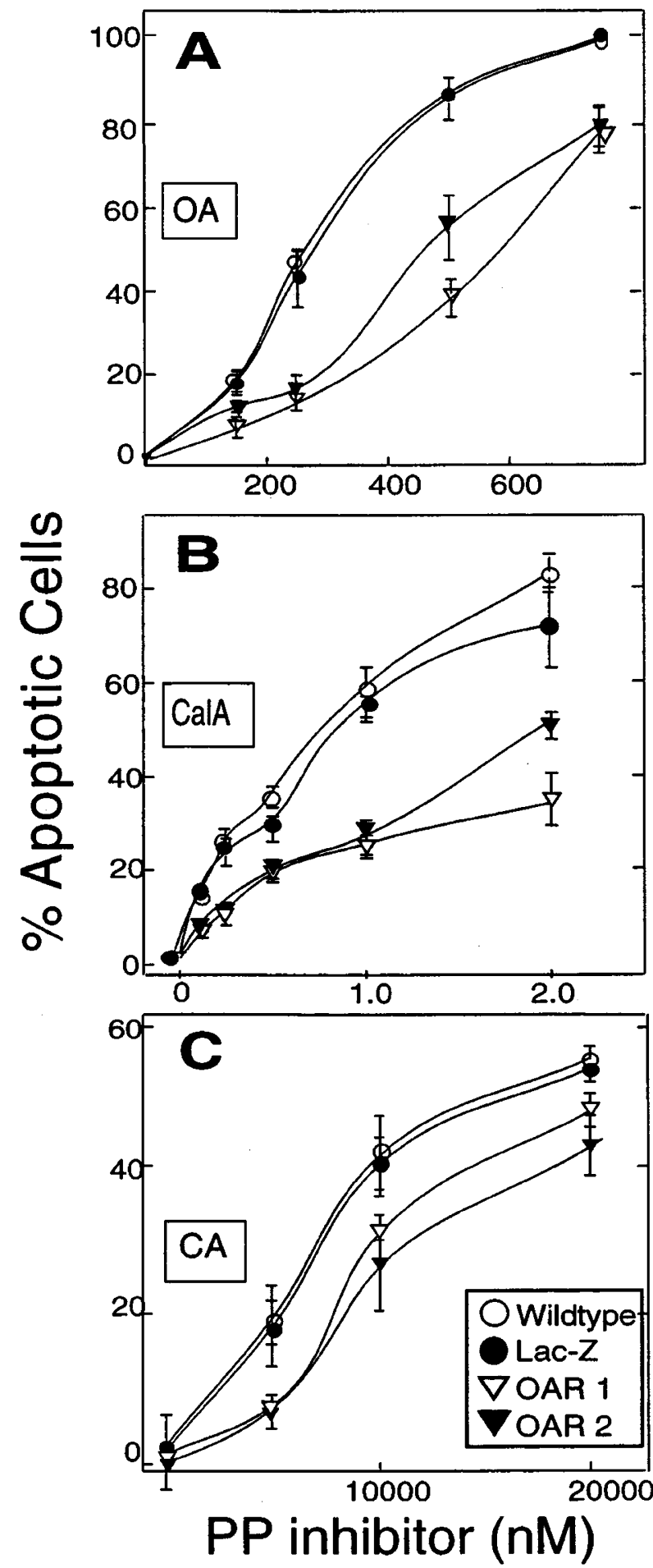

Figure 4 OAR clones show cross-resistance to the various $\mathrm{PP}$ inhibitors $\mathrm{OA}$ (A) Cal A (B) or CA (B). Cells were treated for $3 \mathrm{~h}$ with increasing concentrations of the serine/threonine protein phosphatase inhibitors okadaic acid $(\mathrm{OA})$, calyculine $\mathrm{A}(\mathrm{Cal} A)$ or cantharidin $(\mathrm{CA})$. The per cent apoptosis is shown for control cells (C3H/10T1/2 Cl 8 wild-type and $\mathrm{C} 3 \mathrm{H} / 10 \mathrm{~T} 1 / 2 \mathrm{Cl} 8$ - LACZ), OAR1, and OAR2. For further details of cell culturing, see Materials and Methods and the legend to Figure 2. Each point represents the mean of results from at least three separate experiments + S.E.M.

case of multidrug resistance in OAR1 and 2 one would expect these cell clones to be protected against other apoptosis inducing drugs like staurosporine and doxorubicin. Staurosporine depends on a mitochondrial pathway to induce apoptosis, whereas doxorubicin has several attack points, including DNA by topoisomerase inhibition, oxidation of cellular components, and induction of FAS/CD95 and Fas-ligand. ${ }^{56-58}$ Wild-type and OAR cells were equally susceptible to death induction by these two agents (data not shown). This indicated that the pathway blocked in OAR1 and OAR2 and responsible for OA-induced death was not shared by these other apoptotic agents, and that the multidrug resistance was an improbable explanation for the OA resistance in OAR1 and 2. Verapamil is known to reverse multidrug resistance by inhibiting drug efflux. ${ }^{35,37,59}$ No reversal of OA resistance was observed in OAR1 or OAR2 cells pre-treated with verapamil (data not shown), providing an additional argument against an upregulation of multidrug resistance related genes in OAR1 and 2.

\section{OAR1 and OAR2 have intact major PP1/PP2A activity, but show distinct and subtle alterations in the OA-induced phosphoprotein pattern}

Next it was considered whether PP2A or PP1 had become down regulated in the OAR cells. Direct assays of phosphohistone dephosphorylation activity in the cells as well as of ${ }^{125} \mathrm{I}$-microcystin-YR binding activity failed to show any significant difference between wild-type cells and OAR1 and 2. Furthermore, the sensitivity towards $O A$ of the catalytic activity and the ${ }^{125} \mathrm{I}$-microcystin-YR binding activity were similar (data not shown). This assay would only pick up gross alterations of the major OA-targets PP1 or PP2A, and it was therefore decided for study the phosphoprotein pattern in intact cells treated with $\mathrm{OA}$ to detect potential subtle differences in protein phosphorylation between cell clones. Subtle differences in phosphorylation pattern can occur even if PP1 and PP2A are similarly expressed and inhibited by OA. One possibility is altered compartmentalisation of PP relative to the substrate another possibility is that the phosphorylation site is made more or less accessible due to interaction with another protein. A third possibility is that protein kinases activities can be different between wild-type cells, OAR1 and OAR2. As shown in Figure 5 a number of proteins (spots a, b1, b2, c2 (c1, c3), d1, d2, d3, e, f, h, k, I, j1, j2, j3, and m2 - 5) showed increased phosphorylation in response to OA in both the wild-type cells and in the two clones. This indicates that $\mathrm{OA}$ is able to inhibit the major protein phosphatases in the resistant clones. Interestingly, subtle differences existed in the OA-stimulated protein phosphorylation pattern between maternal cells, OAR1 and OAR2 (Figure 5). A row of $53.5 \mathrm{kDa}$ phosphoprotein spots $(\mathrm{m} 1-\mathrm{m} 5$ in the highlighted insets of Figure 5; probably vimentin based on migration in the gels) and spot $g$ showed less pronounced hyperphosphorylation in both OAR 1 and 2 than in the control cells. Even more challenging was the observation of selective upregulation of protein phoshorylation by OA in OAR1 (spots i1, i2, c4, c5, c6, c7) and in OAR2 (spots c4, c5, c6, c7). No protein staining was observed corresponding to these ${ }^{32} \mathrm{P}$ labelled protein spots $\mathrm{i} 1$, i2, and $\mathrm{c} 4-\mathrm{c} 7$, precluding microsequencing of the 

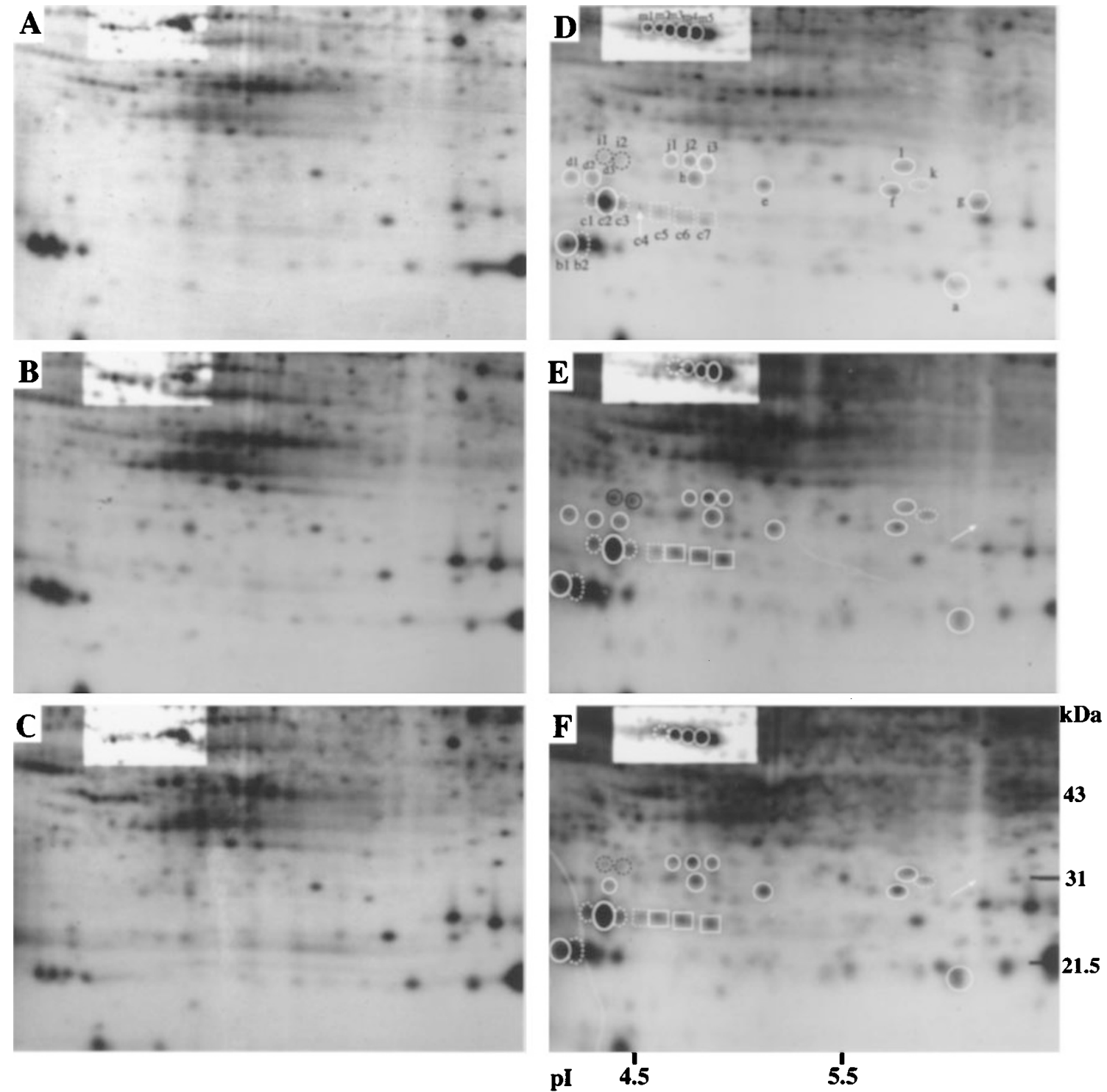

Figure 5 Comparison of the OA-induced protein phosphorylation in control and OAR cells. The panels show autoradiographs after 2-dimensional electrophoresis of extracts from different cell clones labelled with ${ }^{32} \mathrm{Pi}$ and incubated $(2 \mathrm{~h})$ in the absence $(\mathbf{A}, \mathbf{B}, \mathbf{C})$ or presence (D, E, F) of $250 \mathrm{nM}$ OA. The upper right panels $(\mathbf{A}, \mathbf{D})$ represent control cells ( $\mathrm{C} 3 \mathrm{H} / 10 \mathrm{~T} 1 / 2 \mathrm{Cl} 8$ wild-type), the middle panels (B, E) OAR1, and the lower panels (C, F) OAR2. OA-induced phosphoprotein spots are labelled by letters a-m (D) according to increasing apparent molecular size, and by numbers according to decreasing isolelectic $\mathrm{pH}$ (pl). Solid lines surround strongly OA-induced spots and weakly induced spots are surrounded by dashed lines. The spots in white circles were induced by OA in all cell clones. Spot $\mathrm{g}$ (indicated by a diamond in D) in control cells was absent in OAR1 and OAR2. Spots represented by rectangles (c4-c7) were stronger for OAR1 and OAR2 than for wild-type cells. Black circles (i1, i2) indicate spots that were much stronger in OAR1 than in OAR2 and control cell extracts. The arrows point to expected positions of induced spots. In an area, corresponding to the presumed position of vimentin, the autoradiograph was overexposed. It is therefore replaced by the same area from a $3 \times$ shorter exposure (see highlighted area). The autoradiographs are representative for three separate experiments. The molecular masses of protein standards and pl values are indicated on the ordinate and the abscissa, respectively $(\mathbf{F})$. For further details see Materials and Methods and Fladmark et al. ${ }^{29}$

corresponding proteins in the present stage of analytical scale gel loading. In a separate set of experiments cells were incubated with ${ }^{33} \mathrm{Pi}$ rather than ${ }^{32} \mathrm{Pi}$, for only $1.5 \mathrm{~h}$ in order to enhance the autoradiographic resolution. At this early time point only a minor increase of protein phosphorylation was noted, and then only for spots common for wild-type and OAR cells (not shown). It should be noted that spots i1-2 and c47 were not apparent at this early stage in wild-type cells, indicating that their absence in these cells (Figure 5) was not due to a downregulation after an early transient increase.

\section{OAR1 and OAR2 are protected against the caspase-dependent and -independent component of OA-induced death, but not against the caspase-dependent death inducers Cytochrome $c$ and staurosporine}

Caspases can be engaged early in the chain of events leading to apoptosis, like in the rapid activation of procaspase- 8 in response to CD95 trimerisation in some cells. ${ }^{60,61}$ They can also be late executioners of apoptosis, as in the response to 
staurosporine where mitochondrial dysfunction leads to release of Cytochrome (Cyt $c$ ) and thereby activation of caspases-3 and 9. ${ }^{62-64}$ The broadly acting caspase inhibitor zVAD-fmk ${ }^{5,65}$ at 20 (not shown) and $50 \mu \mathrm{M}$ counteracted OAinduced apoptosis in wild-type cells, and also protected against the residual OA-induced apoptosis in OAR1 and OAR2 (Figure 6). An increase of the zVAD-fmk concentration to 90 or $200 \mu \mathrm{M}$ (not shown) did not result in significantly improved protection against death. Since zVAD-fmk has little activity towards caspase-2, and is only moderately effective against caspase- $6,{ }^{66}$ we tested whether the caspase-2 inhibitor z-VDVAD-fmk and the caspase- 6 inhibitor z-VEID$\mathrm{fmk}^{67,68}$ could protect against OA-induced death. Caspase- 6 inhibitor $(50,100$ and $150 \mu \mathrm{M}$ tested) had no effect on OAinduced apoptosis in any of the cell clones (not shown). The caspase-2 inhibitor gave a moderate protection (18-25\%) of OA-induced apoptosis in lac-z expressing control cells, OAR2 (Figure 6) and OAR1 (not shown). There was no additional protection when caspase-2 inhibitor (or caspase-6 inhibitor) was added together with 50 or $90 \mu \mathrm{M}$ zVAD-fmk (Figure 6 and data not shown). This indicated that all the cell lines had a component (about 50\%) of caspase independent (OAinduced) cell death, since it resisted inhibitors considered efficient against all known caspases. This led to the conclusion that the OA-induced apoptosis was enhanced by, but not dependent on, caspases, presumably so that a caspase-dependent amplification loop existed between an initial OA-induced apoptosis triggering pathway and a final common execution pathway. Since OAR1 and OAR2 showed similar degree of resistance towards the caspase-dependent and the caspase-independent component of OA-induced death it was considered most likely that the molecular defects in OAR1 and OAR2 were either upstream or

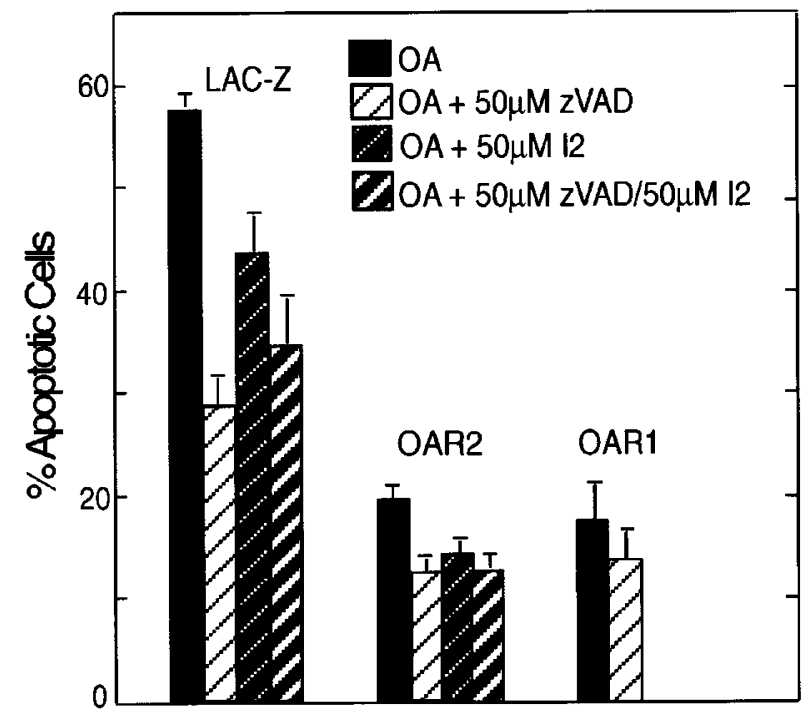

Figure 6 The caspase dependence of OA-induced apoptosis. The figure shows the inhibition of OA-induced apoptosis by $50 \mu \mathrm{M}$ of the general caspase inhibitor zVAD-fmk, or by $50 \mu \mathrm{M}$ of the caspase-2 directed inhibitor (I2) when tested separately and in combination. OAR1, OAR2 and control (LAC-Z) cells were compared. Cells were pre-incubated for $1 \mathrm{~h}$ in the presence caspase inhibitor followed by a $3 \mathrm{~h}$ treatment with $250 \mathrm{nM} \mathrm{OA}$. The data represent the mean of three to seven separate experiments \pm S.E.M. downstream of the postulated caspase amplification loop. In case the defect was downstream of the caspase amplification loop one would expect that also other caspase dependent death pathways should be affected in OAR1 and 2. This was tested by comparing the effect of microinjected cyt $c$ in control, OAR 1 and 2 cells. Cyt $c$, when released from mitochondria into the cytosol, interacts with apoptosis inducing factor-1 (apaf-1) and thereby triggers a caspase cascade activation involving caspase-3 and 9. ${ }^{62,69}$ Recent experiments reveal that direct microinjection of cyt $c$ into cytocol trigger caspase activation and induce apoptotic cell death in several different cell lines. ${ }^{70-72}$ Both control cells (C3H/10T1/2 Cl 8-LAC-Z) and the OA-resistant cell clone (OAR1) started to undergo apoptosis as early as 10-20 min after injection (Figure 7), reaching $100 \%$ apoptosis $60 \mathrm{~min}$ after injection, in both cell clones. These results show that apaf- 1 and caspases-3/9 are fully active in our cell clones, and suggest that the apoptotic defect in these clones resides upstream of apaf-1 and activation of caspases-3 and 9.

Three possible pathways upstream of caspase activation have been suggested to be relevant for OA-induced apoptosis. One is the induction of death-promoting proteins through enhanced transcription followed by translation and/or downregulation of survival proteins through decreased transcription. ${ }^{6,68,73}$ Another possible pathway is antagonism of a cell survival pathway through inhibition of phosphatidylinositol 3-kinase activity. ${ }^{74}$ The

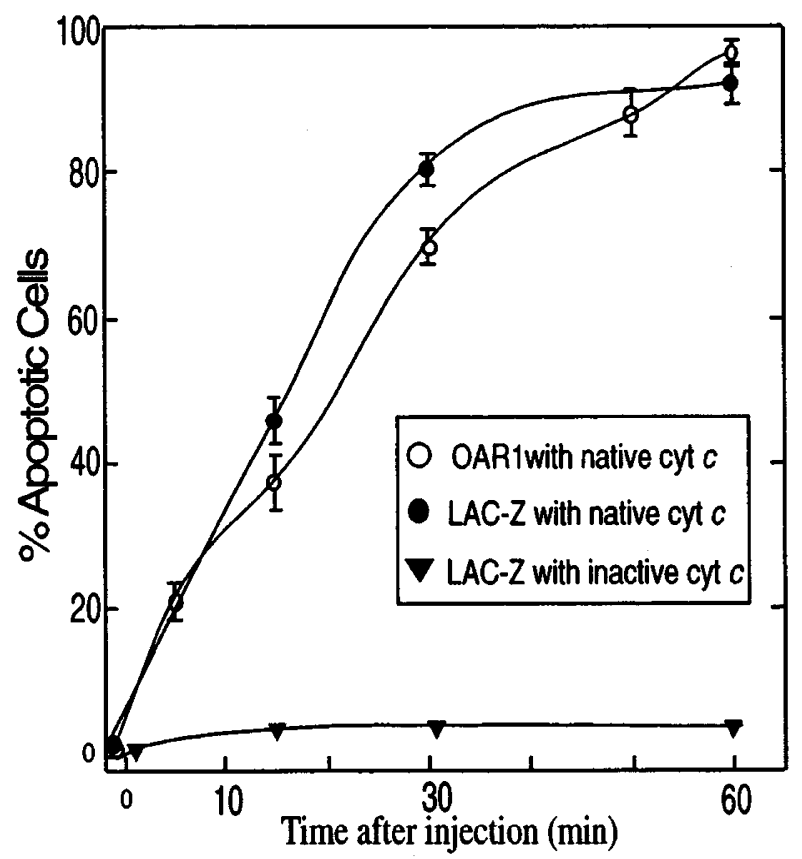

Figure 7 Cyt $c$ kills OA-resistant cells with similar kinetics as control cells. Cells were seeded in $35 \mathrm{~mm}$ dishes with grid pattern, $18 \mathrm{~h}$ prior to injection. Apoptotic cells were observed at different time points after injection, and per cent apoptosis plotted against time. OAR1 cells were injected with native cyt $c$ (open circles), and $\mathrm{C} 3 \mathrm{H} / 10 \mathrm{~T} 1 / 2 \mathrm{Cl} 8-\mathrm{LAC}-\mathrm{Z}$ with native (filled circles) or inactive (filled triangles) cyt $c$. For further details see Materials and Methods. Data represent the mean of three separate experiments (involving injections of $50-100$ cells $) \pm$ S.E.M. 
third is through enhanced production ceramide. ${ }^{75}$ The transcriptional regulation by $\mathrm{OA}$ can be abrogated through inhibition of protein synthesis by e.g. cycloheximide. The postulated OA-induced inhibition of phosphatidylinositol 3kinase can be mimicked by the inhibitor wortmannin and ceramide action by short chain ceramide.

We first examined if the OA-induced cell death was dependent on the novo protein synthesis by treating the cell with cyclohexemide ( 1 and $10 \mu \mathrm{g} / \mathrm{ml}$ ) for $30 \mathrm{~min}$, followed by OA treatment for $3 \mathrm{~h}$ (data not shown). Little or no effect was observed by cyclohexemide treatment alone, nor did cyclohexemide effect OA-induced apoptosis in any of the cell clones tested. These results indicate that the protein mediators required for $\mathrm{OA}$-induced cell death are constitutively expressed in $\mathrm{C} 3 \mathrm{H} / 10 \mathrm{~T} 1 / 2 \mathrm{Cl} 8$ cells, and they are neither short-lived nor induced to an important degree by OA. This was true both for the parental cells and the OAR clones.

If $\mathrm{OA}$ induce apoptosis through phosphatidylinositol 3kinase inhibition in $\mathrm{C} 3 \mathrm{H} / 10 \mathrm{~T} 1 / 2 \mathrm{Cl} 8$ cells, it was possible that OA-treated OAR1 or OAR2 cells had hyperactive phosphatidylinositol 3-kinase. In order to probe this possibility the phosphatidylinositol 3-kinase inhibitor wortmannin was tested for ability to induce apoptosis or modulate OA-induced apoptosis in $\mathrm{C} 3 \mathrm{H} / 10 \mathrm{~T} 1 / 2 \mathrm{Cl} 8-$ LAC-Z, C3H/10T1/2 Cl 8 wild-type, OAR1, and OAR2 cells. No effect of wortmannin (given $1 \mathrm{~h}$ before $\mathrm{OA}$ challenge, and tested at concentrations from $10 \mathrm{nM}$ to $10 \mu \mathrm{M}$ ) was noted for any of the cell clones (data not shown). This suggested that (1) inhibition by $O A$ of phosphatidylinositol 3-kinase either did not occur or was insufficient to induce apoptosis in the $\mathrm{C} 3 \mathrm{H} / 10 \mathrm{~T} 1 / 2 \mathrm{Cl} 8$ cells, and (2) that the resistance in OAR1 and 2 was not due to wortmannin-inhibitable phosphatidylinositol 3-kinase activity. Finally it was tested whether C8-ceramide (up to $200 \mu \mathrm{M}$ ) could induce apoptosis in the $\mathrm{C} 3 \mathrm{H} / 10 \mathrm{~T} 1 / 2 \mathrm{Cl} 8-$ LAC-Z cells and OAR2. Only minor increase in apoptotsis (up to $10 \%$ ) was noted (data not shown).

It can be concluded that the defects in OAR1 and OAR2 involve pathways not previously implicated in OA apoptosis signalling.

\section{Discussion}

The present study describes the establishment, by retrovirusmediated cDNA-library expression screening, of cell clones resistant to okadaic acid (OA)-induced apoptosis. The mRNA produced from the retrovirally-introduced CDNA was recovered from the two cell clones (OAR1 and OAR2), reversed transcribed and DNA sequenced.

Retrovirus-mediated cDNA-library expression screening is a powerful and rather recent technique ${ }^{76}$ used to detect novel oncogenes, ${ }^{77-79}$ and to detect novel modulators of Fas-mediated apoptosis ${ }^{39}$ and p53 tumour-supressor activity. ${ }^{80}$ The presently used C3H/10T1/2 fibroblasts were readily infected by retrovirus ( $>99 \%$ infection), and had no background resistance to $\mathrm{OA}$. For these reasons this cellsystem was choosen for screening an entire cDNA library. In order to enhance the power of the method the library contained cDNA in both sense- and antisense-orientation, and included short cDNAs. In this way it was expected to pick up (1) full-length genes coding for anti-apoptotic proteins, (2) fragments of genes coding for peptides with potential dominant negative action towards OA-induced apoptosis, and (3) genes encoding pro-apoptoptic proteins expressed in the antisense direction.

The use of such a library may explain why so many OAresistant cell clones (21 from 10 million infected cells, or 1 per 500,000 cells) were obtained. Previous attempts to establish $O A$ resistance through natural selection, when cells were exposed to low concentrations of OA for a period of several weeks to months, resulted in only a few cell clones. ${ }^{35,38}$ Such a long treatment period predisposes to the accumulation of spontaneous mutations, gene duplications, and gene silencing. These potential problems were minimised with the present approach. Random retroviral insertion into the genome could, however, activate, silence or truncate genes, and thereby cause OA-resistance unrelated to the cDNA carried by the retroviral vector. Such a mechanism for OA-resistance had to be rare in our system. No 'spontaneously' resistant clones were recovered from 2 million $\mathrm{C} 3 \mathrm{H} / 10 \mathrm{~T} 1 / 2 \mathrm{Cl} 8$ fibroblast infected with retrovirus carrying the lac- $z$ gene, and otherwise exposed to the same OA treatment as the cells infected with retrovirus containing the library (the present study).

The inserted cDNA was recovered and identified from RNA isolated from two of the OA-resistant cell clones (OAR1 and 2), and re-introduced into cells by stable transfection. The re-introduced cDNA re-produced OAresistance, proving that the isolated cDNA was indeed responsible for the observed resistance.

Previously described OA-resistant cell clones were produced using a stepwise increase of OA concentration from $8 \mathrm{nM}$ to up to $300 \mathrm{nM}$ during a long period. In all cases the major OA-resistance could be accounted for by upregulation of the multidrug-resistance gene, $m d r 1$, encoding the P-gp. ${ }^{35,37}$ In one case, part of the $\mathrm{OA}$ resistance was probably due to mutations making PP2A slightly less sensitive to OA, but not to calyculin $A{ }^{38}$ The presently isolated OA-resistant cell clones (OAR1 and 2) were cross-resistant to OA, calyculin A and cantharidin, and the resistance was unaffected by verapamil. This argues against multidrug resistance up-regulation in OAR1 and 2. The increase of protein phosphorylation in response to $\mathrm{OA}$ (judged by $2 \mathrm{D}$ electrophoresis of ${ }^{32} \mathrm{P}$ pre-labelled cells) was strong in OAR1 and OAR2. This suggests that the presently described OA-resistant cells had an intact OA uptake and an intact OA inhibition of the major protein phosphatases (Figure $8 \mathrm{~A}$ ). They are therefore different from all previously described OA-resistant cell lines.

Mitochondria and caspases have key roles in apoptosis, and it was considered whether the cell lines with deficient OA-induced apopotosis had subresponsive mitochondrial or caspase pathways of apoptosis. Mitochondrial damage may induce apoptosis by efflux of Cyt $c$, and activation of caspases and apoptosis inducing factors. ${ }^{81,82}$ The drug staurosporine is known to induce apoptosis through the mitochondrial pathway. ${ }^{62}$ Wild-type $\mathrm{C} 3 \mathrm{H} / 10 \mathrm{~T} 1 / 2 \mathrm{Cl} 8$ fibro- 


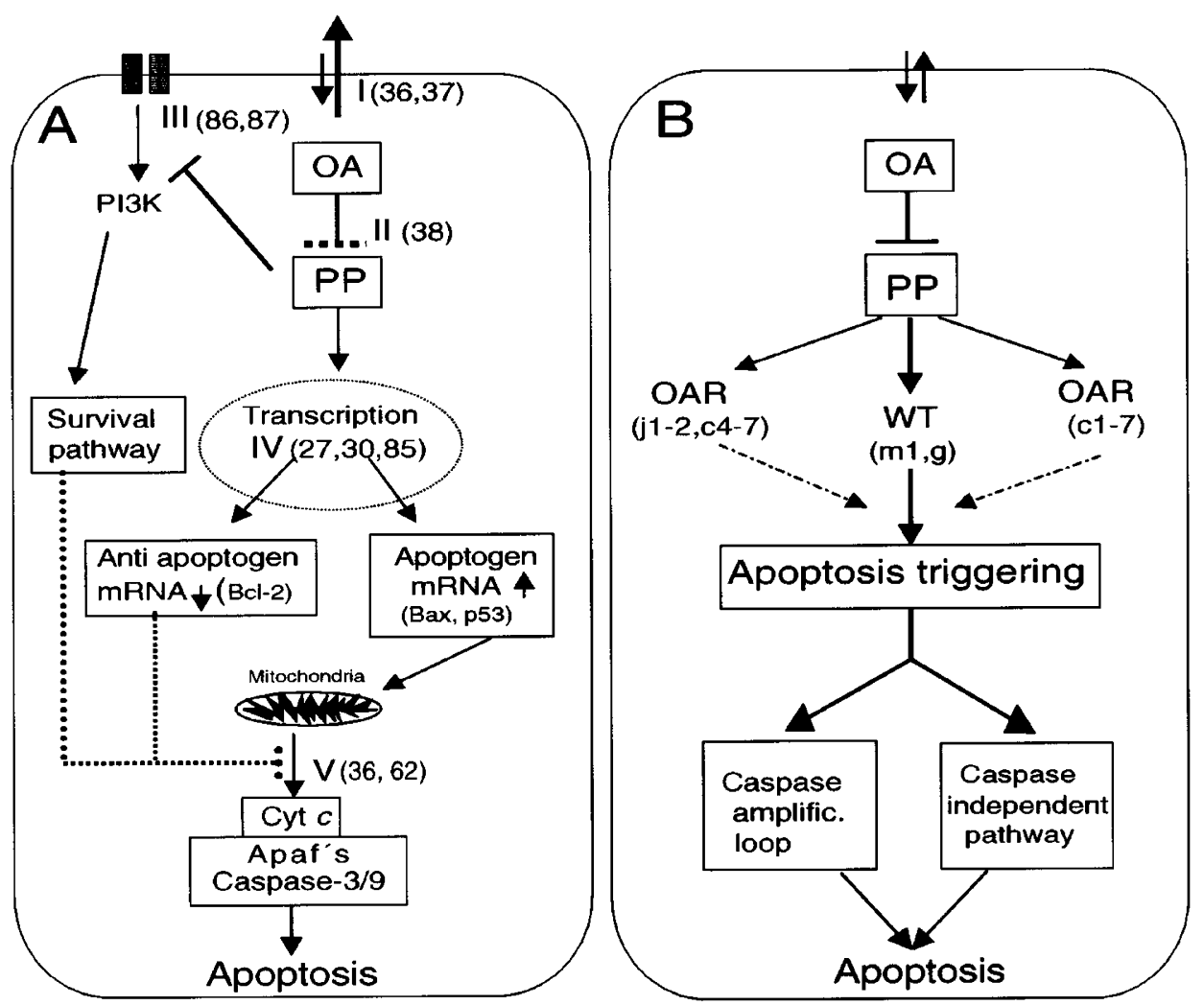

Figure 8 Potential pathways of OA-induced apoptosis (A) A simplified overview of pathways (II-V) previously implicated in OA-induced apoptosis, or mechanisms suggested as responsible for OA-resistance in cell lines (I, III). As detailed in the Results and Discussion sections, the OA-resistance of OAR1 and OAR2 could not be accounted for by increased efflux (I), defects in PP2A (II), or decreased PI3K activity (III). Neither was there evidence for the involvement of newly transcribed genes (IV) or cyt $c(\mathrm{~V})$ in the action of OA. The parenthesis associated with I-V contains references to relevant figures and articles in the reference list. (B) Proposed pathways of $O A$ action in the presently studied cells. It is proposed that different modulator proteins become phosphorylated in response to OA treatment in control, OAR1 and OAR2 cells (see Figure 5) resulting in a delay in the apoptosis triggering in OAR1 and OAR2 compared to control cells (the letters $j 1-2, c 4-7$ etc. indicate spots in Figure 5). OA-induced apoptosis occurs via a caspase dependent and caspase independent pathway both for OAR1, OAR2 and control (see Figure 6)

blasts, OAR1 and 2 had similar sensitivity to staurosporine. This indicates that the mitochondrial apoptosis pathway was not impaired in the OA-resistant cell clones.

Activation of one or more of the 14 known caspases (for review, see $^{4,5}$ ) is a major component of apoptosis, but there is also growing evidence of caspase-independent cell death. ${ }^{7,83-85}$ It is possible that the caspases can function as amplification loops superimposed on an underlying caspase-independent pathway of death. This may explain our recent observation in caspase-3-deficient MCF-7 cells, where enforced expression of procaspase- 3 made the nodularin-induced death occur more rapidly, but otherwise resulted in similar apoptotic death. ${ }^{29}$ It is also consistent with the results of the present study, in which the $\mathrm{C} 3 \mathrm{H} /$ $10 \mathrm{~T} 1 / 2 \mathrm{Cl} 8$ fibroblasts were only partly protected against OA-induced apoptosis by caspase inhibitors. The wild-type cells and the OAR clones were protected to a similar degree by caspase inhibitors, suggesting that the defect in the cells did not involve any caspase amplification loop. This was supported by experiments in which microinjection of Cyt $c$ induced apoptosis to the same extent and with similar time kinetics in both wild-type and OAR clones. Since Cyt $c$ action depends on apaf- 1 as well as caspases-
3 and $9,{ }^{62,81}$ this proves that these molecules are intact in OAR1 and 2 (Figure 8A).

The OAR clones had intact response to a number of caspase-dependent death inducers like Cyt $c$, doxorubicin and staurosporine, and therefore most likely had an intact apoptosis execution machinery, suggesting that the defect in OAR1 and OAR2 was upstream, rather than downstream, of caspase activation. Since the OA accumulation appeared normal and the first target, the major protein phosphatases, were intact in OAR1 and OAR2 the defect(s) are most likely located downstream of inhibition of protein phosphatases and upstream of activation of a possible caspase amplification loop (Figure 8B).

Three routes have been postulated to exist for OA action between phosphatase activation and caspase activation. One is through transcriptional regulation, by activation of killer genes like $\mathrm{Bax}^{30,86}$ or by downregulation of antiapoptogens like $\mathrm{Bcl}-2 .{ }^{27}$ Another is through inhibition of a survival signalling pathway involving phospahatidylinositol 3 kinase ${ }^{87,88}$ and a third through the production of ceramide. ${ }^{75}$ In the presently studied fibroblasts, OA could induce apoptosis when protein synthesis was blocked. This was true both for the full OA-response in the non-resistant 
cells and the residual OA-response in OAR1 and OAR 2 . This suggests (1) that $O A$ action was independent of new protein synthesis and hence did not act via increased synthesis of proapoptotic gene products, and (2) that the OA-resistant cell clones did not depend on continuous protein synthesis to maintain their resistant state. The phosphatidylinositol-3 kinase inhibitor wortmannin and short chain ceramide failed to either mimic or modulate OA action. It is concluded that the deficient OA-response in OAR 1 and 2 cannot readily be explained by any mechanism previously implicated in OA-induced death (summarised in Figure 8A).

To obtain clues about the steps between OA inhibition of phosphatases and apoptosis triggering in the presently studied cells, they were subjected to $2 \mathrm{D}$ analysis of their phosphoproteins before and after OA treatment. The OAinduced phosphoprotein pattern was scrutinised for differences between wild-type cells, OAR1 and OAR2. Two phosphoprotein spots were selectively not induced by OA in OAR1 and OAR2. Five protein spots were induced by OA in OAR1, but not in wild-type cells. Three of the latter protein spots were induced also in OAR2 (summarised in Figure $8 B$ ). Identification of these phosphoproteins can help elucidate the aspects of OA signalling, downstream of PP inhibition.

In conclusion, the present study has shown the feasibility of introducing a retroviral expression library to produce cell clones with resistance to apoptogens like okadaic acid. The two cell clones (OAR1 and 2) selected for further scrutiny had defects in the OA-response that were distinct from those in previously reported OA-resistant cell lines, and the resistance could not be explained by mechanisms previously proposed to mediate OA-induced cell death. The sequencing of the cDNA corresponding to the mRNA expressed from the cDNA integrated in OAR1 and 2 did not identify any known proteins, but rather to two recently sequenced genes (AP000795 and AK002158) of completely unknown function. The elucidation of how the cDNAs of OAR1 and 2 work to alter protein phsophorylation, and how this is coupled to triggering apoptosis may shed new light on the mechanisms of OA-induced apoptosis.

\section{Materials and Methods}

\section{Chemicals and reagents}

Verapamil, cantharidin, okadaic acid, colchicine, cyclohexemide, hexadimethrine bromide (polybrene), biszbenzimide fluorochrome (Hoechst 33342), chloramine T and dimethyl sulfoxide (DMSO) were from Sigma (St Louis, MO, USA). Calyculin A, microcystin-YR, caspase-2 inhibitor (z-VDVAD-fmk; Z-Val-Asp (OMe)-Val-Ala-Asp (OMe)- $\mathrm{CH}_{2} \mathrm{~F}$ ) and caspase-6 inhibitor (z-VEID-fmk; Z-Val-Glu (Ome)-Ile-Asp (OMe)- $\mathrm{CH}_{2} \mathrm{~F}$ ) were from Calbiochem (San Diego, CA, USA). The caspase inhibitor z-val-ala-DL-asp-fluormethylketone (zVAD-fmk) was from Bachem Feinchemikal AG (Bubendorf, Switzerland). Oligonucleotides used as primers and probes were from Medprobe (Oslo, Norway). Carrierfree $\mathrm{Na}^{125} \mathrm{I}, \mathrm{P}^{33_{\mathrm{i}}}, \mathrm{P}^{32} \mathrm{i}$ and $\left[\gamma-\mathrm{P}^{32}\right]$ ATP were from Amersham (Little Chalfont, UK). Protein phosphatase $2 \mathrm{~A}$ was kindly provided by Dr EmmaVilla-Moruzzi University of Pisa. ${ }^{89}$

\section{Cell culture}

Mouse embryonic fibroblasts, $\mathrm{C} 3 \mathrm{H} / 10 \mathrm{~T} 1 / 2 \mathrm{Cl} 8,{ }^{90}$ and Phoenix-Eco virus producer cells (transformed human emryonic kidney cells, 293T, ATCC; CCRL 11269), were cultured in Dulbecco's modified Eagle's medium (DMEM) supplemented with $10 \%$ heat inactivated foetal calf serum, streptomycin $(5 \mu \mathrm{g} / \mathrm{ml})$ and penicillin $(5 \mathrm{U} / \mathrm{ml})$.

For labelling of cellular phosphoproteins the cells were preincubated in serum-free DMEM without phosphate. After thirty minutes $O A$ or control vehicle was added. Sixty minutes after OA addition ${ }^{32} \mathrm{Pi}$ was added $(1 \mathrm{mCi} / \mathrm{ml}$ of medium), and after another $90 \mathrm{~min}$ the reaction was stopped by the addition of trichloroacetic acid to a final concentration of $7 \%$, and the phosphoproteins sedimented, redissolved, and subjected to 2D-PAGE analysis as described by Fladmark et al. ${ }^{29}$

\section{Virus production}

A Jurkat T-cell cDNA library, constructed in the retrovirus vector pBabeMN, ${ }^{40-42}$ was used to produce recombinant replication defect retrovirus. The bi-directionally-oriented cDNA library, containing $10^{6}$ independent cDNA inserts, was a kind gift from Dr Nolan, Stanford Medical University.

Recombinant, helper-free retrovirus was produced according to previously described procedures ${ }^{47}$ with a few modifications: The Ecotrophic virus packaging cell line Phoenix-Eco (ATCC; CCRL 11269) was transfected with the pBabeMN-Jurkat CDNA library by calcium phosphate-DNA co-precipitation. The incubation temperature was decreased from $37^{\circ} \mathrm{C}$ to $32^{\circ} \mathrm{C} 24 \mathrm{~h}$ after transfection to enhance the stability of virus released into the medium.

Recombinant virus was harvested from the cell supernatant $48 \mathrm{~h}$ after transfection, and immediately applied to target cells, without any freezing and thawing steps.

The concentration of infectious virus was determined by exposing $\mathrm{C} 3 \mathrm{H} / 10 \mathrm{~T} 1 / 2 \mathrm{Cl} 8$ cells to virus containing the lac-z reporter gene (pBabeMN-Z-I), ${ }^{40}$ followed by $\beta$-galalactosidase staining. In brief, cells were seeded at a density of $10^{5}$ cells per well, $18 \mathrm{~h}$ prior to virus transduction. Infection/transduction was performed according to ${ }^{47}$ in the presence of $8 \mu \mathrm{g} / \mathrm{ml}$ hexadimethrine bromide (polybrene) (Sigma). The temperature was $32^{\circ} \mathrm{C}$ during the first $12 \mathrm{~h}$ and $37^{\circ} \mathrm{C}$ during the following $12 \mathrm{~h}$. Staining for $\beta$-galactocidase expression was essentially according to. ${ }^{91}$ The cells were fixed for $2 \mathrm{~min}$ in $100 \mathrm{mM}$ sodium phosphate buffer (PBS) pH 7.3 containing $2 \%$ formaldehyde and $2 \%$ glutaraldehyde, washed three times with PBS pH 7.3, overlaid with the staining solution. After $20 \mathrm{~h}$ incubation at $37^{\circ} \mathrm{C}$ and $14-18 \mathrm{~h}$ at $4^{\circ} \mathrm{C}$, the number of blue-stained cells were estimated by bright-field light microscopy at $200 \times$ magnification.

\section{cDNA library screening in $\mathrm{C} 3 \mathrm{H} / 10 \mathrm{~T} 1 / 2$ clone8 fibroblasts}

$\mathrm{C} 3 \mathrm{H} / 10 \mathrm{~T} 1 / 2 \mathrm{Cl} 8$ cells $\left(10^{6}\right)$ were seeded in $10 \mathrm{~cm}$ tissue-culture dishes. Ten dishes (about $10^{7}$ cells) were transduced with $3 \times 10^{6}$ infectious units of Jurkat T-cell cDNA library in retrovirus, as described above. Thirty per cent transduction was achieved as determined by doping the library with reporter retrovirus pBabeMN-Lac-Z (1/10) and staining for $\beta$-galactosidase activity. Control cells were transduced with retrovirus containing $\mathrm{pBabeMN-Lac-Z \text {. }}$

Transduced cells were treated with $750 \mathrm{nM}$ of $\mathrm{OA}$ for $48 \mathrm{~h}$. Additional medium containing $750 \mathrm{nM} \mathrm{OA}$ was added after $24 \mathrm{~h}$ in order to ensure that degradation of $O A$ should not influence the results. Cells that survived the treatment were grown to subconfluence and treated again with OA for $48 \mathrm{~h}$ as described above. 
Single cell clones remaining after the second round of elimination, were isolated by local trypsin treatment using cloning cylinders (Sigma) and expanded in 24 well plates (one clone per well), and grown to $70 \%$ confluence before further analysis.

\section{Isolation, cloning and sequencing of transduced cDNAs}

Total RNA was isolated from two of the OA-resistant clones according to Chomczynski, ${ }^{92}$ and used to produce cDNA by reverse transcription PCR (RT-PCR), according to the manufacturers instruction using the GeneAmp RNA PCR Core Kit from Perking Elmer/Cetus. A primer specific for the virus vector was used for cDNA synthesis $\left(5^{\prime}\right.$ TTTCTGGAGACTAAATAAAATCTT-3' (bmn4)). For first round PCR, 5'-CCTCGATCCCTTTATCCAG-3' (pBabe2) was used as upper primer and Bmn4 as lower primer. For the second round PCR; 5 TCAAAGTAGACGCCATCG-3' (bmn2) was the upper primer and 5'ATCGTCGACCACTGTGCT-3' (bmn3) the lower primer. In each reaction (first and second round) the PCR was run for 25 cycles (30 sec at $94^{\circ} \mathrm{C}, 30 \mathrm{sec}$ at $55^{\circ} \mathrm{C}$ and $30 \mathrm{sec}$ at $72^{\circ} \mathrm{C}$ ) and a final extension for $10 \mathrm{~min}$ at $72^{\circ} \mathrm{C}$ to ensure a proper A-tailing by the TaqPolymerase. Amplified PCR products were purified from a low-melting point agarose gel (Sigma) and cloned into a TA-cloning vector (pCR-IITopo) using standard TA-TOPO cloning techniques (Invitrogen). Cloned cDNAs were sequenced by BigDyeDeoxy Terminator Cycle Sequencing kit (Applied Biosystems) and the sequences were analysed on an Applied Biosystems Model 377 sequencer. The cDNAs corresponding to RNA from OAR1 and 2 (oar1 and oar2, respectively) were isolated from pCR-II-Topo vector digested with EcoRI enzyme, and cloned into a pBabe-derived retrovirus vector, containing the neomycin selection marker gene, pBMN-I-n. ${ }^{40}$

\section{Transfection of isolated cDNAs into $\mathrm{C} 3 \mathrm{H} / 10 \mathrm{~T} 1 / 2$ Cl 8 wild-type cells}

$\mathrm{C} 3 \mathrm{H} / 10 \mathrm{~T} 1 / 2 \mathrm{Cl} 8$ wild-type cells were transfected with pBMN-I-n carrying oar2 in the sense orientation and oar1 in either sense or antisense orientation, followed by selection for 4 weeks in G418 (1.0 mg/ml; GibcoBRL).

Single surviving cells were isolated by local trypsination, using cloning cylinders, and expanded. Stable transfectants were confirmed to contain the relevant cDNA by RT-PCR from total RNA, as previously described. cDNA synthesis was performed using virus vector specific primer IresH; 5'-CACATTGCCAAAAGACGG-3', followed by further PCR amplification with primers specific for either oar2 (5'AACTCTCTGTGCTGCTCT-3' (Oar2-1) and 5'-CCGCAAATCTCATAATGC-3' (Oar2-3)), or oar1 (5'-GTCCCCTTTCCAGCACAC-3' (Oar1-1) and 5'-GTGTGCTGGAAAGGGGAC-3' (Oar1-2)). Amplified PCR fragments were further confirmed by Southern blot analysis and hybridisation with $\left[\gamma-\mathrm{P}^{32}\right]$-ATP end-labelled oligonucleotides specific for oar1 (5'-GATTCTCTCTCTGTGGTAGAGAATGG-3') or oar2 (5'AGTGAGTAAAAGTCCGCA-3'). Similarly, transfectants were established with pBMN-I-n (empty vector) and pBMN-Z-I-n (lac-z containing virus vector) for control experiments.

\section{Microinjection of cells with Cytochrome $c$}

Cells were seeded in $35 \mathrm{~mm}$ dishes with a grid pattern forming $4 \mathrm{~mm}^{2}$ squares, 40000 cells per dish. The microinjection was performed as described previously. ${ }^{70}$ The intracellular concentration of Cyt $c$ was estimated to be $20 \mu \mathrm{M}$, according to previously described calculations. ${ }^{93}$ Cyt $c$ was co-injected routinely with TRITC-dextran (Sigma) at
$0.1 \mu \mathrm{g} / \mu \mathrm{l}$ (intracellular) concentration, to detect positive cells by fluorescence microscopy. Control injections were performed with TRITC-dextrane in $\mathrm{H}_{2} \mathrm{O}$ alone, and with an inactive, hexa-biotinylated, cyt $c$ (Sigma).

\section{Determination of apoptosis}

The $\mathrm{C} 3 \mathrm{H} / 10 \mathrm{~T} 1 / 2 \mathrm{Cl} 8$ cells were routinely seeded in 48-well plates, at a density of 5000 cells per well the day before apoptosis-inducing treatments were commenced.

After treatment, cells were fixed in PBS containing $2 \%$ formaldehyde and $10 \mu \mathrm{g} / \mathrm{ml}$ of the DNA specific dye bisbenzimide (Hoechst 33342; Sigma). Apoptosis was determined microscopiocally, using Hoffmann polarisation to improve the morphological evaluation, and fluorescence microsopy to evaluate chromatin condensation.

\section{Assay of cellular content of PP}

Cells $\left(10^{6}\right)$ were cultured in $10 \mathrm{~cm}$ culture dishes, harvested into PBS, and pelleted at (1000 r.p.m. for $3 \mathrm{~min}$ ). Cell extract was prepared by resuspending the pellets in $0.5 \mathrm{ml}$ of ice-cold $50 \mathrm{mM}$ Tris- $\mathrm{HCl}(\mathrm{pH} 7.6)$ buffer with $0.1 \mathrm{mM}$ EDTA, 2-mercaptoetanol $(0.1 \%)$ and a cocktail of different protease inhibitors (antipain, pepsin, chymostatin, aprotinin, leupeptin, and PMSF). The suspension was immediately homogenised for $3 \times 2 \mathrm{sec}$ with an Ultra Turrax T5FU homogeniser at $20000 \mathrm{rev} / \mathrm{min}$. The homogenate was centrifuged at 13000 r.p.m. for $15 \mathrm{~min}$ at $4^{\circ} \mathrm{C}$ to produce a high-speed supernatant. The cell extract was assayed at various dilutions $(10-100)$ in $0.5 \mathrm{ml} 50 \mathrm{mM} \mathrm{Hepes}(\mathrm{pH} 7.2)$ buffer $^{94}$ for PP activity using ${ }^{32} \mathrm{P}$-labelled phospho-histone as substrate, essentially as previously described..$^{94}$ It was also assayed for capacity to bind $\left[{ }^{125} \mathrm{I}\right]$ microcystin-YR (present at $5 \mathrm{nM}$ and about 6000 d.p.m.). PP2A, PP1, PP4, and PP5 have high-affinity interaction with microcystins, ${ }^{19,21,94}$ and should be detected by the assay. The incubation was routinely carried out over night at $2^{\circ} \mathrm{C}$, and $\left[{ }^{125} \mathrm{I}\right]$ microcystin-YR bound to PP was determined by scintillation counting of the macromoleculeassociated $\left[{ }^{125} \mathrm{I}\right]$ microcystin-YR, as described previously. ${ }^{94}$ The assay was performed in the absence and presence of PP2A inhibitor (30$80 \mathrm{nM} \mathrm{OA}$ ). These concentrations were able to block microcystin binding to the added PP2A, but not to added PP1 (not shown).

\section{Acknowledgements}

We are grateful to Dr. Jim Lorenz and Prof. GP Nolan for providing Jurkat T-cell $c D N A$ library and lac-z reporter gene in a retrovirus vector system. The excellent technical assistance of Nina Lied Larsen, Erna Finsås, and Gro Gausdal is highly appreciated, and we are indebted to Margrethe Serres for helping with the PP binding and activity assays. This work was supported by grants from the Norwegian Cancer Society (DNK) and from the Novo Nordic Insulin Foundation.

\section{References}

1. Kerr JF, Wyllie AH and Currie AR (1972) Apoptosis: a basic biological phenomenon with wide-ranging implications in tissue kinetics. Br. J. Cancer 26: $239-257$

2. Vaux DL, Haecker G and Strasser A (1994) An evolutionary perspective on apoptosis. Cell 76: 777-779

3. Wyllie AH, Kerr JF and Currie AR (1980) Cell death: the significance of apoptosis. Int. Rev. Cytol. 68: 251-306 
4. Nicholson DW and Thornberry NA (1997) Caspases: killer proteases. Trends Biochem. Sci. 22: 299-306

5. Villa P, Kaufmann SH and Earnshaw WC (1997) Caspases and caspase inhibitors. Trends Biochem. Sci. 22: 388-393

6. Wolf BB and Green DR (1999) Suicidal tendencies: apoptotic cell death by caspase family proteinases. J. Biol. Chem. 274: 20049-20052

7. Bortner CD and Cidlowski JA (1999) Caspase independent/dependent regulation of $\mathrm{K}(+)$, cell shrinkage, and mitochondrial membrane potential during lymphocyte apoptosis. J. Biol. Chem. 274: 21953-21962

8. Miller TM, Moulder KL, Knudson CM, Creedon DJ, Deshmukh M, Korsmeyer SJ and Johnson Jr. EM (1997) Bax deletion further orders the cell death pathway in cerebellar granule cells and suggests a caspase-independent pathway to cell death. J. Cell. Biol. 139: 205-217

9. Wolf BB, Goldstein JC, Stennicke HR, Beere H, Amarante-Mendes GP, Salvesen GS and Green DR (1999) Calpain functions in a caspase-independent manner to promote apoptosis- like events during platelet activation. Blood 94: 1683-1692

10. Allen RT, Cluck MW and Agrawal DK (1998) Mechanisms controlling cellular suicide: role of Bcl-2 and caspases. Cell Mol. Life Sci. 54: 427-445

11. Chao DT and Korsmeyer SJ (1998) BCL-2 family: regulators of cell death. Annu. Rev. Immunol. 16: 395-419

12. Choisy-Rossi $C$ and Yonish-Rouach $E$ (1998) Apoptosis and the cell cycle: the p53 connection [editorial; comment]. Cell Death Differ. 5: 129-131

13. Kasten MM and Giordano A (1998) pRb and the cdks in apoptosis and the cell cycle. Cell Death Differ. 5: $132-140$

14. Holmstrom TH and Eriksson JE (2000) Phosphorylation-Based signaling in Fas receptor-mediated apoptosis. Crit. Rev. Immunol. 20: 121-152

15. Janke C, Gartner U, Holzer M and Arendt T (1998) Reversible in vivo phosphorylation of tau induced by okadaic acid and by unspecific brain lesion in rat. J. Hirnforsch. 39: 143-153

16. Shimizu T, Cao CX, Shao RG and Pommier Y (1998) Lamin B phosphorylation by protein kinase calpha and proteolysis during apoptosis in human leukemia HL60 cells. J. Biol. Chem. 273: 8669-8674

17. Yatsunami J, Fujiki H, Suganuma M, Yoshizawa S, Eriksson JE, Olson MO and Goldman RD (1991) Vimentin is hyperphosphorylated in primary human fibroblasts treated with okadaic acid. Biochem. Biophys. Res. Commun. 177: $1165-1170$

18. Gjertsen BT and Doskeland SO (1995) Protein phosphorylation in apoptosis. Biochim. Biophys. Acta. 1269: 187-199

19. Cohen PT (1997) Novel protein serine/threonine phosphatases: variety is the spice of life. Trends Biochem. Sci. 22: 245-251

20. Cohen PT, Brewis ND, Hughes V and Mann DJ (1990) Protein serine/threonine phosphatases; an expanding family. FEBS Lett. 268: 355-359

21. Honkanen RE, Codispoti BA, Tse K, Boynton AL and Honkanan RE (1994) Characterization of natural toxins with inhibitory activity against serine/threonine protein phosphatases [published erratum appears in Toxicon 1994 Apr;32(4):519]. Toxicon. 32: 339-350

22. Fujiki $H$ and Suganuma $M$ (1999) Unique features of the okadaic acid activity class of tumor promoters. J. Cancer Res. Clin. Oncol. 125: 150-155

23. Boe R, Gjertsen BT, Vintermyr OK, Houge G, Lanotte M and Doskeland SO (1991) The protein phosphatase inhibitor okadaic acid induces morphological changes typical of apoptosis in mammalian cells. Exp. Cell. Res. 195: 237-246

24. Gjertsen BT, Cressey LI, Ruchaud S, Houge G, Lanotte M and Doskeland SO (1994) Multiple apoptotic death types triggered through activation of separate pathways by cAMP and inhibitors of protein phosphatases in one (IPC leukemia) cell line. J. Cell. Sci. 107: 3363-3377

25. Kiguchi K, Glesne D, Chubb CH, Fujiki H and Huberman E (1994) Differential induction of apoptosis in human breast tumor cells by okadaic acid and related inhibitors of protein phosphatases 1 and 2A. Cell Growth Differ. 5: 995-1004

26. Lerga A, Richard C, Delgado MD, Canelles M, Frade P, Cuadrado MA and Leon J (1999) Apoptosis and mitotic arrest are two independent effects of the protein phosphatases inhibitor okadaic acid in K562 leukemia cells. Biochem. Biophys. Res. Commun. 260: 256-264

27. Riordan FA, Foroni L, Hoffbrand AV, Mehta AB and Wickremasinghe RG (1998) Okadaic acid-induced apoptosis of HL60 leukemia cells is preceded by destabilization of bcl-2 mRNA and downregulation of bcl-2 protein. FEBS Lett. 435: $195-198$
28. Sieder S, Richter E, Becker K, Heins R and Steinfelder HJ (1999) Doxorubicinresistant LoVo adenocarcinoma cells display resistance to apoptosis induction by some but not all inhibitors of ser/thr phosphatases 1 and 2A. Toxicology 134 $109-115$

29. Fladmark KE, Brustugun OT, Hovland R, Boe R, Gjertsen BT, Zhivotovsky B and Doskeland SO (1999) Ultrarapid caspase-3 dependent apoptosis induction by serine/threonine phosphatase inhibitors. Cell Death Differ. 6: 1099-1108

30. Li DW, Fass U, Huizar I and Spector A (1998) Okadaic acid-induced lens epithelial cell apoptosis requires inhibition of phosphatase- 1 and is associated with induction of gene expression including p53 and bax. Eur. J. Biochem. 257: $351-361$

31. Woodgate A, Walton M, MacGibbon GA and Dragunow M (1999) Inducible transcription factor expression in a cell culture model of apoptosis. Brain Res. Mol. Brain Res. 66: 211-216

32. Yan Y, Shay JW, Wright WE and Mumby MC (1997) Inhibition of protein phosphatase activity induces p53-dependent apoptosis in the absence of p53 transactivation. J. Biol. Chem. 272: 15220-15226

33. KikuchiK, Shima H, Mitsuhashi S, Suzuki Mand Oikawa H (1999) The apoptosisinducing activity of the two protein phosphatase inhibitors, tautomycin and thyrsiferyl 23-acetate, is not due to the inhibition of protein phosphatases PP1 and PP2A (review). Int. J. Mol. Med. 4: 395-401

34. Kawamura T, Matsuzawa S, Mizuno Y, Kikuchi K, Oikawa H, Oikawa M, Ubukata M and Ichihara A (1998) Different moieties of tautomycin involved in protein phosphatase inhibition and induction of apoptosis. Biochem. Pharmacol. 55: $995-1003$

35. Chambers TC, Raynor RL and Kuo JF (1993) Multidrug-resistant human KB carcinoma cells are highly resistant to the protein phosphatase inhibitors okadaic acid and calyculin A. Analysis of potential mechanisms involved in toxin resistance. Int. J. Cancer 53: 323-327

36. Krautheim A, Brechlin P, BeckerK, Winkler Mand Steinfelder HJ (2000) Hamster pancreatic beta cell lines with altered sensitivity towards apoptotic signalling by phosphatase inhibitors. Br. J. Pharmacol. 129: 687-694

37. Zheng B, Chambers TC, Raynor RL, Markham PN, Gebel HM, Vogler WR and Kuo JF (1994) Human leukemia K562 cell mutant (K562/OA200) selected for resistance to okadaic acid (protein phosphatase inhibitor) lacks protein kinase Cepsilon, exhibits multidrug resistance phenotype, and expresses drug pump $\mathrm{P}$ glycoprotein. J. Biol. Chem. 269: 12332-12338

38. Shima H, Tohda H, Aonuma S, Nakayasu M, DePaoli-Roach AA, Sugimura Tand Nagao M (1994) Characterization of the PP2A alpha gene mutation in okadaic acid-resistant variants of CHO-K1 cells. Proc. Natl. Acad. Sci. USA. 91: $9267-$ 9271

39. Hitoshi Y, Lorens J, Kitada SI, Fisher J, LaBarge M, Ring HZ, Francke U, Reed JC, Kinoshita S and Nolan GP (1998) Toso, a cell surface, specific regulator of Fas-induced apoptosis in T cells. Immunity 8: 461-471

40. Kinsella TM and Nolan GP (1996) Episomal vectors rapidly and stably produce high-titer recombinant retrovirus. Hum. Gene Ther. 7: 1405-1413

41. Kitamura T, Onishi M, Kinoshita S, Shibuya A, Miyajima A and Nolan GP (1995) Efficient screening of retroviral cDNA expression libraries. Proc. Natl. Acad. Sci. USA. 92: $9146-9150$

42. Onishi M, Kinoshita S, Morikawa Y, Shibuya A, Phillips J, Lanier LL, Gorman DM, Nolan GP, Miyajima A and Kitamura T (1996) Applications of retrovirus-mediated expression cloning. Exp. Hematol. 24: 324-329

43. Kissil JL, Deiss LP, Bayewitch M, Raveh T, Khaspekov G and Kimchi A (1995) Isolation of DAP3, a novel mediator of interferon-gamma-induced cell death. J. Biol. Chem. 270: 27932-27936

44. Inbal B, Shani G, Cohen O, Kissil JL and Kimchi A (2000) Death-associated protein kinase-related protein 1, a novel serine/threonine kinase involved in apoptosis. Mol. Cell Biol. 20: 1044-1054

45. Khwaja $A$ and Tatton $L$ (1999) Resistance to the cytotoxic effects of tumor necrosis factor alpha can be overcome by inhibition of a FADD/caspasedependent signaling pathway. J. Biol. Chem. 274: 36817-36823

46. Raveh T, Berissi H, Eisenstein M, Spivak T and Kimchi A (2000) A functional genetic screen identifies regions at the $\mathrm{C}$-terminal tail and death-domain of death-associated protein kinase that are critical for its proapoptotic activity. Proc. Natl. Acad. Sci. USA. 97: 1572-1577 
47. Pear WS, Nolan GP, Scott ML and Baltimore D (1993) Production of high-titer helper-free retroviruses by transient transfection. Proc. Natl. Acad. Sci. USA. 90: $8392-8396$

48. Benson DA, Boguski MS, Lipman DJ, Ostell J, Ouellette BF, Rapp BA and Wheeler DL (1999) GenBank. Nucleic Acids Res. 27: 12-17

49. Tateno Y and Gojobori T (1997) DNA Data Bank of Japan in the age of information biology. Nucleic Acids Res. 25: 14-17

50. Stoesser G, Tuli MA, Lopez R and Sterk P (1999) The EMBL Nucleotide Sequence Database. Nucleic Acids Res. 27: 18-24

51. Arnaud E, Touriol C, Boutonnet C, Gensac MC, Vagner S, Prats $H$ and Prats AC (1999) A new 34-kilodalton isoform of human fibroblast growth factor 2 is cap dependently synthesized by using a non-AUG start codon and behaves as a survival factor. Mol. Cell Biol. 19: 505-514

52. Nanbru C, Lafon I, Audigier S, Gensac MC, Vagner S, Huez G and Prats AC (1997) Alternative translation of the proto-oncogene c-myc by an interna ribosome entry site. J. Biol. Chem. 272: 32061-32066

53. Packham G, Brimmell M and Cleveland JL (1997) Mammalian cells express two differently localized Bag-1 isoforms generated by alternative translation initiation. Biochem. J. 328: 807-813

54. Honkanen RE (1993) Cantharidin, another natural toxin that inhibits the activity of serine/threonine protein phosphatases types 1 and 2A. FEBS Lett. 330: 283 286

55. Sakurada K, Zheng B and Kuo JF (1992) Comparative effects of protein phosphatase inhibitors (okadaic acid and calyculin A) on human leukemia HL60, HL60/ADR and K562 cells. Biochem. Biophys. Res. Commun. 187: 488-492

56. Blagosklonny MV, Robey R, Bates S and Fojo T (2000) Pretreatment with DNAdamaging agents permits selective killing of checkpoint-deficient cells by microtubule-active drugs. J. Clin. Invest. 105: 533-539

57. Friesen C, Fulda S and Debatin KM (1999) Induction of CD95 ligand and apoptosis by doxorubicin is modulated by the redox state in chemosensitive-and drug-resistant tumor cells. Cell Death Differ. 6: 471-480

58. Friesen C, Fulda S and Debatin KM (1999) Cytotoxic drugs and the CD95 pathway. Leukemia. 13: 1854-1858

59. Futscher BW, Foley NE, Gleason-Guzman MC, Meltzer PS, Sullivan DM and Dalton WS (1996) Verapamil suppresses the emergence of P-glycoproteinmediated multi-drug resistance. Int. J. Cancer. 66: 520-525

60. Medema JP, Scaffidi C, Kischkel FC, Shevchenko A, Mann M, Krammer PH and Peter ME (1997) FLICE is activated by association with the CD95 death-inducing signaling complex (DISC). Embo J. 16: 2794-2804

61. Peter ME and KrammerPH(1998) Mechanisms of CD95 (APO-1/Fas)-mediated apoptosis. Curr. Opin. Immunol. 10: 545-551

62. Bossy-Wetzel E and Green DR (1999) Apoptosis: checkpoint at the mitochondrial frontier. Mutat. Res. 434: 243-251

63. Sun XM, MacFarlane M, Zhuang J, Wolf BB, Green DR and Cohen GM (1999) Distinct caspase cascades are initiated in receptor-mediated and chemicalinduced apoptosis. J. Biol. Chem. 274: 5053-5060

64. Tang D, Lahti JM and Kidd VJ (2000) Caspase-8 activation and bid cleavage contribute to MCF7 cellular execution in a caspase-3-dependent manner during staurosporine-mediated apoptosis. J. Biol. Chem. 275: 9303-9307

65. Ekert PG, Silke J and Vaux DL (1999) Caspase inhibitors. Cell Death Differ. 6 $1081-1086$

66. Garcia-Calvo M, Peterson EP, Leiting B, Ruel R, Nicholson DW and Thornberry NA (1998) Inhibition of human caspases by peptide-based and macromolecular inhibitors. J. Biol. Chem. 273: 32608-32613

67. Gregoli PA and Bondurant MC (1999) Function of caspases in regulating apoptosis caused by erythropoietin deprivation in erythroid progenitors. J. Cell. Physiol. 178: 133-143

68. Thornberry NA and Lazebnik Y (1998) Caspases: enemies within. Science. 281: $1312-1316$

69. Reed JC (1997) Cytochrome c: can't live with it - can't live without it [comment] Cell 91: 559-562

70. Brustugun OT, Fladmark KE, Doskeland SO, Orrenius S and Zhivotovsky B (1998) Apoptosis induced by microinjection of cytochrome $c$ is caspasedependent and is inhibited by Bcl-2 [published erratum appears in Cell Death Differ 1999 Mar;6(3):301]. Cell Death Differ. 5: 660-668

71. Li F, Srinivasan A, Wang Y, Armstrong RC, Tomaselli KJ and Fritz LC (1997) Cell-specific induction of apoptosis by microinjection of cytochrome c. Bcl-xL has activity independent of cytochrome c release. J. Biol. Chem. 272: 30299-30305
72. Zhivotovsky B, Orrenius S, Brustugun OT and Doskeland SO (1998) Injected cytochrome $\mathrm{c}$ induces apoptosis [letter]. Nature 391: 449-450

73. Nicholson DW (1999) Caspase structure, proteolytic substrates, and function during apoptotic cell death. Cell Death Differ. 6: 1028-1042

74. Mothe I and Van Obberghen E (1996) Phosphorylation of insulin receptor substrate-1 on multiple serine residues, $612,632,662$, and 731 , modulates insulin action. J. Biol. Chem. 271: 11222-11227

75. Spinedi A, Di Bartolomeo S, Di Sano F, Rodolfo C, Ambrosino A and Piacentini M (1999) Ceramide accumulation precedes caspase-dependent apoptosis in CHP-100 neuroepithelioma cells exposed to the protein phosphatase inhibitor okadaic acid. Cell Death Differ. 6: 618-623

76. Kitamura T (1998) New experimental approaches in retrovirus-mediated expression screening. Int. J. Hematol. 67: 351-359

77. Whitehead I, Kirk H and Kay R (1995) Expression cloning of oncogenes by retroviral transfer of cDNA libraries. Mol. Cell. Biol. 15: 704-710

78. Whitehead I, Kirk H and Kay R (1995) Retroviral transduction and oncogenic selection of a cDNA encoding Dbs, a homolog of the $\mathrm{Dbl}$ guanine nucleotide exchange factor. Oncogene 10: 713-721

79. Whitehead IP, Khosravi-Far R, Kirk H, Trigo-Gonzalez G, Der CJ and Kay R (1996) Expression cloning of Isc, a novel oncogene with structural similarities to the $\mathrm{Dbl}$ family of guanine nucleotide exchange factors. J. Biol. Chem. 271: $18643-18650$

80. Hudson JD, Shoaibi MA, Maestro R, Carnero A, Hannon GJ and Beach DH (1999) A proinflammatory cytokine inhibits p53 tumor suppressor activity [see comments]. J. Exp. Med. 190: 1375-1382

81. Cecconi F (1999) Apaf1 and the apoptotic machinery. Cell Death Differ. 6: 1087 1098

82. Daugas E, Nochy D, Ravagnan L, Loeffler M, Susin SA, Zamzami Nand Kroemer G (2000) Apoptosis-inducing factor (AIF): a ubiquitous mitochondrial oxidoreductase involved in apoptosis. FEBS Lett. 476: 118-123

83. Borner C and Monney L (1999) Apoptosis without caspases: an inefficient molecular guillotine? Cell Death Differ. 6: 497-507

84. Eby MT, Jasmin A, Kumar A, Sharma K and Chaudhary PM (2000) TAJ, a novel member of the tumor necrosis factor receptor family, activates the c-Jun $\mathrm{N}$ terminal kinase pathway and mediates caspase-independent cell death. J. Biol. Chem. 275: $15336-15342$

85. Kawahara A, Ohsawa Y, Matsumura H, Uchiyama $Y$ and Nagata S (1998) Caspase-independent cell killing by Fas-associated protein with death domain. J. Cell. Biol. 143: 1353-1360

86. Sheikh MS, Garcia M, Zhan Q, Liu Y and Fornace Jr. AJ (1996) Cell cycleindependent regulation of $\mathrm{p} 21 \mathrm{Waf} 1 / \mathrm{Cip} 1$ and retinoblastoma protein during okadaic acid-induced apoptosis is coupled with induction of Bax protein in human breast carcinoma cells. Cell. Growth Differ. 7: 1599-1607

87. D'Ambrosio C, Valentinis B, Prisco M, Reiss K, Rubini M and Baserga R (1997) Protective effect of the insulin-like growth factor I receptor on apoptosis induced by okadaic acid. Cancer Res. 57: 3264-3271

88. Prisco M, Romano G, Peruzzi F, Valentinis B and Baserga R (1999) Insulin and IGF-I receptors signaling in protection from apoptosis. Horm. Metab. Res. 31 : $80-89$

89. Resink TJ, Hemmings BA, Tung HY and Cohen P (1983) Characterisation of a reconstituted Mg-ATP-dependent protein phosphatase. Eur. J. Biochem. 133: $455-461$

90. Reznikoff CA, Brankow DW and Heidelberger C (1973) Establishment and characterization of a cloned line of $\mathrm{C} 3 \mathrm{H}$ mouse embryo cells sensitive to postconfluence inhibition of division. Cancer Res. 33: 3231-3238

91. Sanes JR, Rubenstein JL and Nicolas JF (1986) Use of a recombinant retrovirus to study post-implantation cell lineage in mouse embryos. Embo J. 5: 31333142

92. ChomczynskiP and Sacchi N (1987) Single-step method of RNA isolation by acid guanidinium thiocyanate- phenol-chloroform extraction. Anal Biochem. 162: $156-159$

93. Mellgren G, Vintermyr OK, Boe R and Doskeland SO (1993) Hepatocyte DNA replication is abolished by inhibitors selecting protein phosphatase $2 \mathrm{~A}$ rather than phosphatase 1. Exp. Cell. Res. 205: 293-301

94. Serres MH, Fladmark KE and Doskeland SO (2000) An ultrasensitive competitive binding assay for the detection of toxins affecting protein phosphatases. Toxicon. 38: $347-360$ 